\title{
Practical Implementation of Structural Health Monitoring in Multi-Story Buildings
}

\author{
Arvindan Sivasuriyan ${ }^{1,2}{ }^{\circledR}$, Dhanasingh Sivalinga Vijayan ${ }^{1}\left(\mathbb{D}\right.$, Wojciech Górski ${ }^{3}$, Łukasz Wodzyński ${ }^{3}$, \\ Magdalena Daria Vaverková ${ }^{3,4}$ (1) and Eugeniusz Koda ${ }^{3, *}$
}

1 Department of Civil Engineering, Aarupadai Veedu Institute of Technology, Vinayaka Missions Research Foundation, Paiyanoor, Chennai 603104, India; arvinds@asa.ac.in (A.S.); vijayan@avit.ac.in (D.S.V.)

2 Anand School of Architecture, Chennai 603103, India

3 Institute of Civil Engineering, Warsaw University of Life Sciences, 159 Nowoursynowska St., 02-776 Warsaw, Poland; wojciech_gorski@sggw.edu.pl (W.G.); lukasz_wodzynski@sggw.edu.pl (Ł.W.); magdalena_vaverkova@sggw.edu.pl (M.D.V.)

4 Faculty of AgriSciences, Mendel University in Brno, Zemědělská 1, 61300 Brno, Czech Republic

* Correspondence: eugeniusz_koda@sggw.edu.pl

check for updates

Citation: Sivasuriyan, A.; Vijayan, D.S.; Górski, W.; Wodzyński, Ł.; Vaverková, M.D.; Koda, E. Practical Implementation of Structural Health Monitoring in Multi-Story Buildings. Buildings 2021, 11, 263. https:// doi.org/10.3390/buildings11060263

Academic Editor: Egidio Lofrano

Received: 23 April 2021

Accepted: 14 June 2021

Published: 20 June 2021

Publisher's Note: MDPI stays neutral with regard to jurisdictional claims in published maps and institutional affiliations.

Copyright: (c) 2021 by the authors. Licensee MDPI, Basel, Switzerland. This article is an open access article distributed under the terms and conditions of the Creative Commons Attribution (CC BY) license (https:/ / creativecommons.org/licenses/by/ $4.0 /)$.

\begin{abstract}
This study investigated operational and structural health monitoring (SHM) as well as damage evaluations for building structures. The study involved damage detection and the assessment of buildings by placing sensors and by assuming weak areas, and considered situations of assessment and self-monitoring. From this perspective, advanced sensor technology and data acquisition techniques can systematically monitor a building in real time. Furthermore, the structure's response and behavior were observed and recorded to predict the damage to the building. In this paper, we discuss the real-time monitoring and response of buildings, which includes both static and dynamic analyses along with numerical simulation studies such as finite element analysis (FEA), and recommendations for the future research and development of SHM are made.
\end{abstract}

Keywords: structural health monitoring; buildings; sensors; accelerometers; damage detection; finite element analysis

\section{Introduction}

SHM systems provide information about any significant change or damage occurring in a structure. The primary purpose of structural damage detection is to identify the reason, location, and type of damage, so as to measure the damage severity and predict the structure's remaining service life. Structural deficiencies causing collapses may result from internal factors, such as corrosion, fatigue, and ageing, and external factors, such as earthquakes, wind loads, and impact loads. The damage caused by the above factors may progress very slowly and become observable only when the structure's damage is considerable, and sometimes it is only repairable at a high cost. The detection of structural damage is essential in ensuring structural safety during a structure's lifetime. The structural damage detection objective is to evaluate the computable and qualitative deterioration of the structural system in service or under a severe load. It is necessary to monitor the location, occurrence, and extent of deterioration from both safety and performance viewpoints. As witnessed by the worldwide development of smart structures and materials, recent advancements in materials and sensing technologies have provided powerful new tools for improving building systems. While many of the structures have existed for decades in their basic form, the intelligence added through the various damage detection methods addresses the practical problems that challenge the effective implementation of active damage control in building structures. SHM has become a primary option for evaluating the overall behavior, preferably from the manufacturing process to the end of its service life. Figure 1 depicts the operating principle of SHM in multi-story buildings along with data acquisition and predictive analysis. 


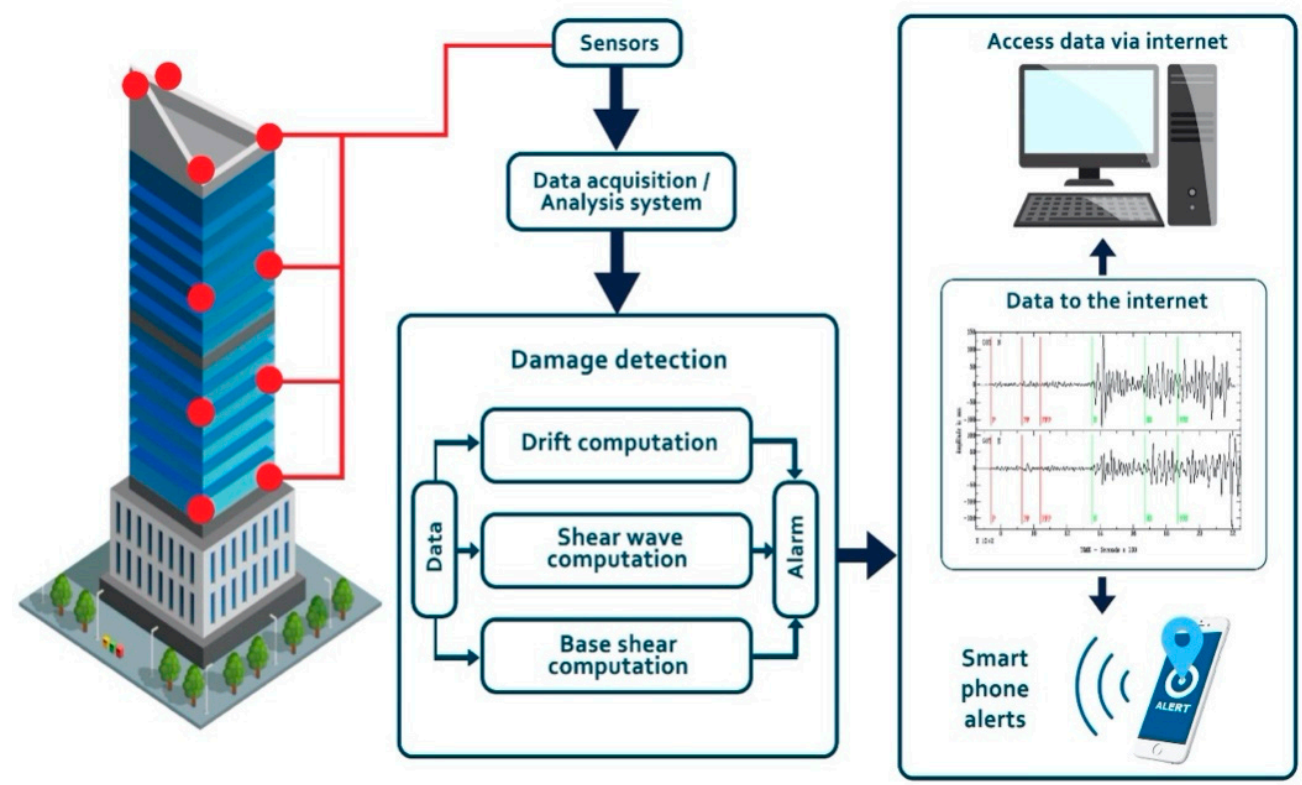

Figure 1. The operating principle of the SHM system in a multi-story building.

Damage detection is an essential consideration in SHM; therefore, a few techniques have been adopted to predict damage such as ambient vibrations. For example, the San Pedro Apostol church was monitored through the SHM technique for both short-term and long-term monitoring to find the variations in temperature and humidity [1]. SHM can be used not only for modern buildings but also for heritage buildings as well, so that historic structures, such as those of the Ottoman Empire, can be monitored using non-destructive techniques (NDTs) to predict damage and observe the current health status of buildings [2,3]. Seismic or any excess acceleration in buildings causes heavy damage to the structure such that the buildings undergo dynamic loading, so dynamic analysis should be carried out using SHM techniques; thus, the forever berated transfer function has been implemented to predict the action of seismic waves in buildings [4]. To diagnose the buildings' damage, by adopting a neural network $(\mathrm{NN})$ approach, both damage and undamaged areas are assessed by applying artificial free vibration to forecast the range and level of damage due to dynamic loading conditions [5].

In SHM, buildings are subjected to static loading conditions for the most part. Furthermore, the main parameter for static loading is displacement, strain, temperature, and acceleration; hence, the deformation and inclination of $600 \mathrm{~m}$ tall canon tower were monitored using SHM in China and found slight changes in deformation in comparatively hot and cold seasons [6]. In general, buildings under static loading will use a 1D or 2D system to carry out monitoring, but by adopting a motion capture system (MCS) instead of a global positioning system (GPS), the structure can be monitored in 3D using advanced sensor technology [7].

The finite element method (FEM) and finite element analysis (FEA) are numerical simulation techniques used to analyze real-time experiments through analytical models using advanced software; hence, complicated analysis, e.g., of stiffness and damping, can be carried out using the FEM technique very easily and reliably, even for multi-story buildings. In one study, a 15\% stiffness reduction was found after analyzing the nine columns, and a $1.67 \%$ stiffness reduction was found in the overall building structure [8]. The FEM was used for steel bracing to identify damage by adopting two methods; namely, the Bayesian estimation method and the weighted least squares methods in the initial stages for the eigen-sensitivity-based FE model [9]. 


\section{Literature Review}

\subsection{Process of SHM}

SHM is an automated system in civil engineering and helps to predict the damage of a structure in early stages with the help of advanced sensing technologies and automated data acquisition techniques, which allows for predictive analysis. This predictive analysis helps companies and researchers to determine the nature, standards, and bearing capacity of a structure against static and dynamic loads. Static loads occur because of displacement, acceleration, strain, stress, and temperature together with dynamic loads based on vibration, natural frequencies, model identification, time history analysis, and response spectrum, depending on the characteristics of the external and internal interactions and the type of structure [10,11]. Olivera Lopez et al. [12] carried out real-time monitoring in a 14-floor building stationed in a coastal area of Chile subjected to dynamic loading. The main objective of the study was to check the withstanding ability of the structure in a tsunami to predict the hydrodynamic forces and detect the damage, and it needs further development in terms of mode deformation. Yanet et al. [13] investigated the lifespan of sensors used for SHM and pointed out that the average life span would be 10 years, and they suggested that more sensors be fixed in a structure to distribute the load equally and enhance the durability and service life of sensors. This technique is known as the communication technology load.

Roghaei and Zabihollah [14] conducted an experimental process in a 3-story hospital steel structure using piezoelectric sensors to identify the stress and deformation by adopting a non-linear static analysis (pushover) approach using SAP2000 and FEMA35 software. Zhou et al. [15] managed to determine damage with an even more accurate vibration-based approach using the hysteresis loop approach (HLA) through an experimental process in a 12-story RC frame building; they determined the variation in stiffness using elastic, hybrid, and pinched approaches, and the results showed that the pinched approach was more effective because it could help to predict variation in fundamental frequencies less than $0.05 \mathrm{~Hz}$. Figure 2 provides detailed information on the progress of SHM in buildings.

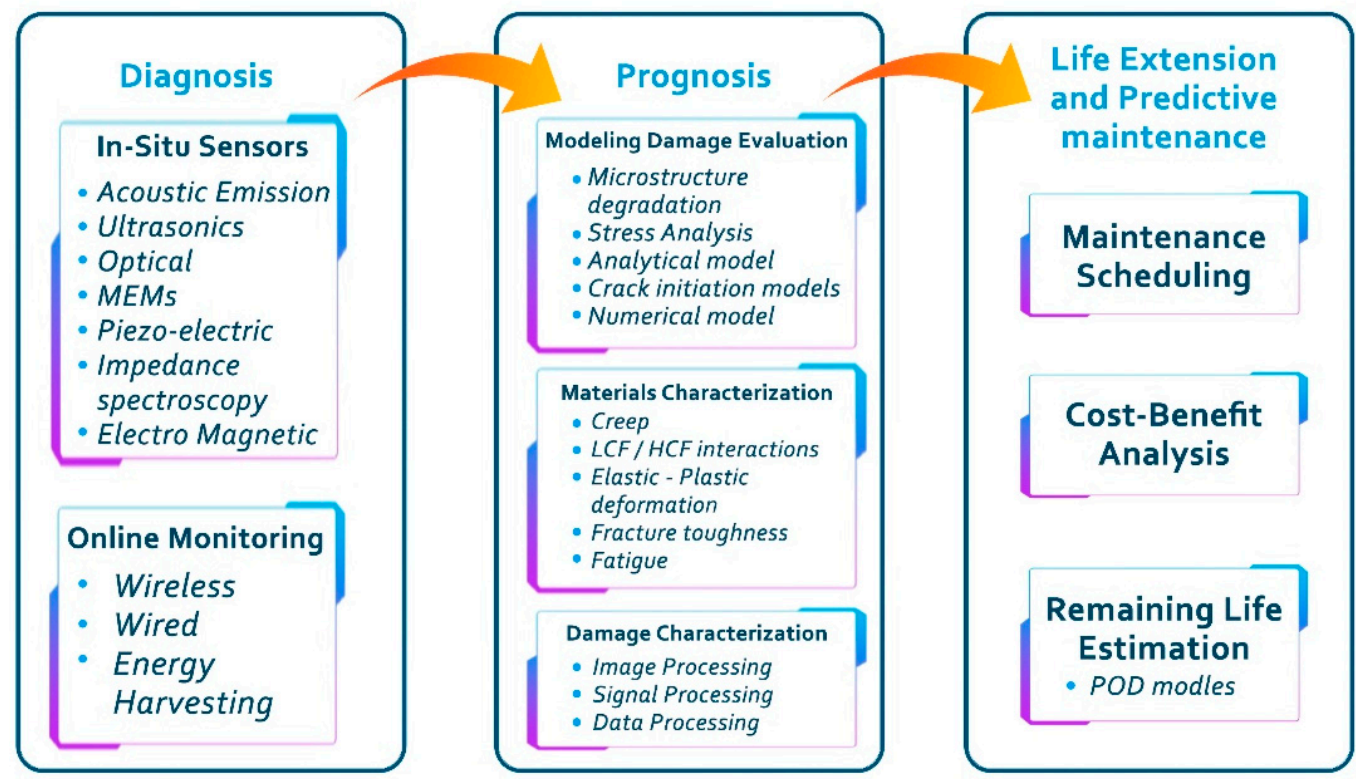

Figure 2. Progression and advancement of SHM in buildings.

Pierdicca et al. [16] carried out long-term monitoring for approximately one year in a reinforced concrete school building to analyze the dynamic behavior of buildings; they used an executing operational ambient vibration survey using an operational model analysis (OMA) approach and developed an FEM model for numerical simulation, and the results of the long-term monitoring approach were satisfactory in terms of economic 
benefits and accuracy. Demetriou et al. [17] presented numerical studies through the on-line monitoring of an existing three-floor building that had been affected due to reductions in stiffness because of the harmonic motion, and the results show that failures occurred at both the first and second floor, stiffness reduction occurred at 1.8 and $4 \mathrm{~s}$, respectively, and no failures occurred at the third floor.

Dong et al. [18] carried out monitoring in two buildings, the Van Nuys hotel and an imperial country service building, by adopting an empirical mode decomposition (EMD) approach and vector aggressive moving average (VARMA) model in order to predict the sensitivity and effectiveness of a damage index based on noise. They reported that the damage index provides valuable information for analyzing damage and examining the relationship between the severity of the damage and the damage index to avoid future problems. Yang et al. [19] carried out real-time monitoring in a 20-story steel frame building in Alaska that was approximately $38.5 \times 38.5 \mathrm{~m}$, and the roof height was $80.5 \mathrm{~m}$ above ground level. This was carried out to analyze the dynamic behavior due to seasonal frost. Vibration data of the building were collected by adopting a permanent strong motion instrumentation system. Simulation was carried out for the foundation at the first phase, and the superstructure was monitored. Furthermore, numerical simulation was also carried out for the same building by assuming concrete as a material instead of steel to evaluate the performance of concrete in the same process. Thus, both concrete and steel simulation models were compared, and results showed that steel buildings outperform concrete building due to the effect of seasonal frost and the anticipated variation in fundamental frequencies of approximately $13 \%$.

\subsection{Sensors Used in SHM}

Antunes et al. [20] carried out both static and dynamic analysis in SHM using optical fiber sensors (OFS) by monitoring an adobe masonry structure and found a reduction in stiffness when natural frequency decreased. A destructive cyclic test was carried out to predict natural frequency, which showed a $48 \%$ reduction [20]. Zhao et al. [21] demonstrated an advanced sensing system, namely, a multiple agent system (MAS), by combining three different types of sensors, piezoelectric sensors, fiber optic sensors, and a strain gauge, to monitor different parameters at the same time, especially for monitoring large structures, and found it to be more effective than conventional sensing systems.

Hison et al. [22] carried out real-time monitoring in a wall structure, namely, the Tufa wall, using magnetoelastic sensors to analyze the elastic deformation and fracture alarm, and this showed good reliability $(1 \mathrm{mV} / 10 \mu \mathrm{m})$ and sensitivity and provided an output that was superior to that of conventional strain meters with low cost.

Mahjoubi et al. [23] studied a Shanghai tower with a $632 \mathrm{~m}$ height by applying a limited number of sensors to predict the damage and behavior of the structure. The ultimate motive of monitoring is to reduce the number of sensors and achieve optimum results, so new sensing technology is adopted, namely, a triaxial accelerometer using a hypotrochoid spiral optimization algorithm, such as flower pollination, lion pride optimization, a teachinglearning-based optimization colony, spiral optimization, particle swarm optimization, and Jaya. Three objective functions of automated modal monitoring by adopting seven algorithms are considered to identify modes. This approach is more effective in high-rise buildings. It cannot be applied to other structures without further research. Figure 3 shows some of the major sensors adopted for SHM. 


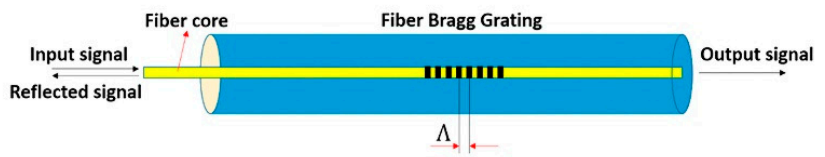

Fibre Optic Sensors

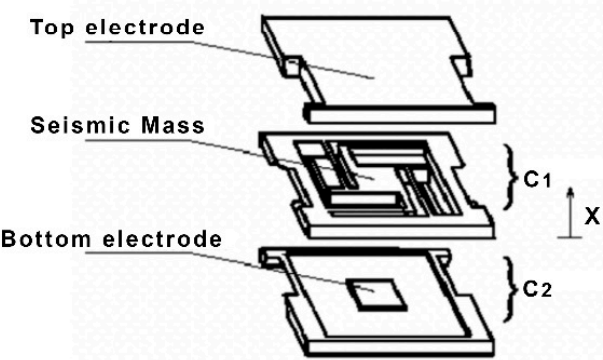

MEMS Accelerometer

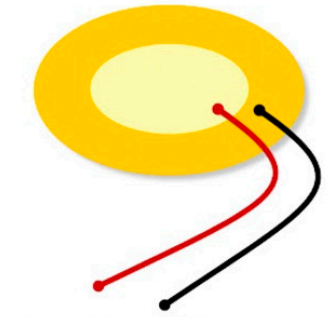

Piezo-Electric sensor

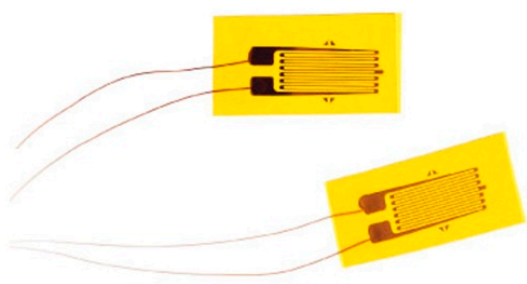

Strain Gauges

Figure 3. Various sensors used for SHM.

\subsection{Overview of the Article}

This study begins with an introduction to SHM in buildings in which the process of SHM and the sensors used for it are discussed, along with strategies of damage detection in previously reported works for real-time monitoring and laboratory experiments. The static and dynamic behavior of buildings implementing SHM is discussed with various methods and approaches. The FEM used to predict building behavior by developing computer models is also discussed. Finally, future research recommendations are reported along with conclusions. Figure 4 provides an overview of SHM applications in buildings.

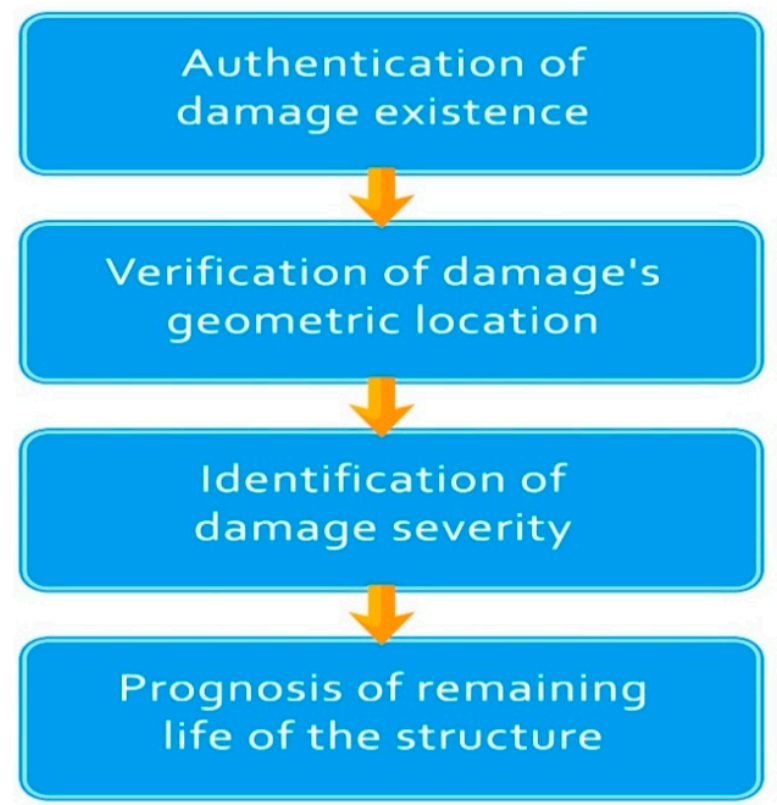

Figure 4. Outline of SHM applications in buildings.

\section{Strategies of Damage Detection in Buildings Using SHM}

Sajedi and Liang [24] conducted an experiment using 44 shake tables. They developed a framework model of a 3-story RC moment frame building, with 180 ground motions and a 5400 non-linear time history analysis, as specified for input using Openness software. 
The simulation report showed that $96 \%, 87 \%$, and $90 \%$ accuracies were predicted for damage existence, location, and severity, respectively. The laboratory experiment showed a $92 \%$ accuracy predicted for damage classes. Gao et al. [25] demonstrated a new a novel embeddable tubular smart aggregate (TSA) evolved from piezo materials and conducted an experiment recording the time of arrival and performing impedance analysis and sweep frequency analysis, and results were satisfactory for 2D concrete structures.

Chatzis et al. [26] carried out a laboratory experiment using shake tables by employing an accelerometer to analyze the severity and location of damage using subspace state-space system identification (SSID) with an advanced version T-SSID approach and an unscented Kalman filter (UKF). They adopted an n4sid algorithm and a Bayesian time-domain, respectively, and compared the T-SSID and UKF. The UKF approach was preferred due to fast approach towards damage prediction. Soltaninejad et al. [27] developed a simulation for two adjacent buildings to anticipate pounding as per a 36-case single-degree-of-freedom model by comparing a short time matrix pencil method (STMPM) and discrete wavelet transform (DWT). The results showed that STMPM helped to predict smaller damage and was not sensitive to the corresponding amplitude of damage response. It also helped to predict damage in both low- and high-resolution sensors. García-Macías and Ubertini [28] examined the Sciri tower located in Italy for approximately one month (February 13 to March 10, 2019) using 12 accelerometers and combined ambient noise deconvolution interferometry (ANDI) and OMA to analyze three levels of frequency, approximately 200, 1000 , and $5000 \mathrm{~Hz}$. This indicated that deformation occurs due to variations in temperature, and wave propagation mode was analyzed.

Sun et al. [29] demonstrated a skyscraper building model, namely, the Al Harma Tower in Kuwait, which is approximately $413 \mathrm{~m}$ in height with 86 floors, using E-tabs together with a building with two curved shear walls to the combined height of the buildings by applying three methods: system identification, interferometry-based wave propagation analysis, and wave-based damage detection. The building underwent large deformations due to heavy dead load and seismic response. Chellini et al. [30] experimented with a composite frame structure of three layouts with three accelerometer sensors to forecast damage in a beam-column joint by conducting a pseudo-dynamic (PSD) and cyclic test using eigen frequencies, a damping ratio, and mode approach. The increase in damping ratio and the high decrease in eigen frequency showed a variation in mode shapes for global sensors, whereas local sensors provided more accuracy and were easy to monitor. Morales-Valdez et al. [31] examined a prototype of a 5-story building with dimensions of $60 \times 50 \times 180 \mathrm{~cm}$ by employing microelectromechanical system (MEMS)-based accelerometer sensor, whose model code is ADXL203E, to predict damage and by adopting a wave propagation algorithm. The damage was assumed as a stiffness reduction using two parameters, namely, the Kelvin damping coefficient and the nominal shear wave velocity, and it was reported that the wave method would outperform the modal analysis method.

Valinejadshoubi et al. [32] developed building information modeling (BIM) to manage data effectively using automated sensor-based data acquisition and a storage module approach to extract sensor data and damage identification. Pachón et al. [33] developed an FE model of a heritage building, i.e., the Monastery of San Jeronimo de Buenavista in Seville in Spain, to predict dynamic behavior such as ambient vibration and model identification to undergo an optimal sensor placement (OSP) technique. The dynamic behavior of buildings consists of four methodologies based on energy matrix rank optimization (SEMRO and KEMRO) and the effective independence of target mode shapes (EFIwm and EFI). The results indicated that EFI provided error to a smaller extent for the natural frequency, and KEMRO provided a large number of errors in modal identification.

Frigui et al. [34] demonstrated an FEM of an 18-story ophite tower with a $2.5 \mathrm{~m}$ height split up into 18 nodes subjected to artificial loading to assume damage severity. They adopted the Modal Assurance Criterion (MAC) method, the Mode Shape Curvature Method (MSCM), Curvature Damage Factor (CDF), the flexibility method, and an algorithm based on the eigen frequencies approach using the vibration-based damage detection 
method (VBDDM. The studies indicated 50\% and 25\% reductions for the first and second artificial damages by the MAC approach; however, a less than 0.8 mode shape is essential, and a more than $5 \%$ eigen frequency is necessary to predict damage. Suhaimi et al. [35] introduced new sensors, namely, passive sensors, to analyze three-dimensional (3D) frequency selective surfaces (FSSs), which are more reliable and enhance sensitivity compared with the 2D FSS structure. García-Macías and Ubertini [36] introduced new software, i.e., MOVA/MOSS, with various types of sensors to predict damage using an automated anomaly detection algorithm by considering the Consoli palace in Italy. Three categories of the model were considered-Principal Component Analysis (PCA), Autoregression with an eXogenous input model (ARX), and Multiple Linear Regression (MLR) - to analyze the local and global damage based on amplitude and resonance frequency.

Li et al. [37] carried out a field study and an FEM on a tall building; namely, the Ping an Finance Centre (PAFC), approximately $600 \mathrm{~m}$ in height and equipped with 553 different sensors, to identify vertical deformation in the various structural elements during the Nida typhoon by applying a modular design methodology. Zhang et al. [38] examined a 108-story $(250 \mathrm{~m}$ ) building, which is 56 stories below and 52 stories above ground level and is equipped with accelerometers and tilt sensors to monitor and predict damage for approximately 15 months based on OMA using a fast Bayesian FFT approach. The results showed a reduction in natural frequencies due to structural mass. Modena et al. [39] investigated heritage structures, namely, a Spanish fortress, a civic tower (L'Aquila), the Scrovengni chapel (Padova), and the stone tomb of Cansignorio, using an SHM approach to analyze the static and dynamic responses of the building. They used a robust statical model and numerical simulation. Mustafa et al. [40] recommended using new advanced wireless sensors (FSS) instead of conventional sensors to predict the damage of buildings with two designs, the circular ring (FSS) and the square loop (FSS). The square loop outperformed the circular loop due to an improved reflection coefficient and incident angle, and it covered a wide frequency range.

Aguilar et al. [41] carried out real-time monitoring for an adobe church in Peru for approximately two years (March 2017 to December 2018) by employing accelerometers to detect damage post-earthquake using a PCA approach and an autoregressive model (ARX). PCA showed more accurate results than ARX (non-linear) in terms of damage prediction. Brownjohn et al. [42] investigated 24 bridges, 3 buildings, 2 chimneys, and 1 tower to ensure communication between the laboratory and the site for transferring the vibration base monitoring (VBM) experimental setup. They found more variation when comparing laboratory and in situ operations and, therefore, suggested real-time monitoring. Coletta et al. [43] monitored a sanctuary of Vicoforte $74 \mathrm{~m}$ in height for approximately four months to predict dynamic behavior for all environmental degradation using various sensors. FE analysis was developed for the same building by adopting support vector machines (SVMs) and relevance vector machines (RVMs) for damage prediction.

García-Macías et al. [44] carried out real-time monitoring for approximately one month (February 13th to March 10th) using an accelerometer with the help of experimental data. An Abaqus FEM was developed to detect damage caused by earthquakes by adopting a Metamodel-based pattern recognition approach, and this helped to identify modal analysis using OMA. Lam et al. [45] monitored a boat-shaped building in Hong Kong; namely, Academic Building 3 (AC3), which is a 20-story building, and five adjacent stories in the subordinate building using the fast Bayesian FFT method, and results indicated changes in readings for the first two days in 12 of the 15 experiments set up due to the carpet in the building, so removing carpet is recommended for accurate vibration measurement. Lorenzoni et al. [46] practiced monitoring with the help of data available for approximately three years in a cultural heritage building, namely, a Spanish fortress with four bastions connected with a $60 \mathrm{~m}$ long wall and a civic tower with a $6.5 \times 7 \mathrm{~m}$ base and a $43 \mathrm{~m}$ height, and developed an ARX model by employing MatLab software. The results suggested that using a robust statistical method and damage detection algorithms is an added advantage when monitoring buildings in any environmental variation. 
Bhalla and Kaur [47], to find equivalence stiffness parameters (ESPs), implemented laboratory testing for reinforced concrete beams using piezo composite concrete vibration sensors (CVSs) to predict low strain fatigue and practice electro-mechanical impedance (EMI). They concluded that CVSs in the EMI mode work more effectively for the initial and final stages of monitoring but not for the intermediate stage. Kaya and Safak [48] developed new software, namely, REC_MIDS based on MatLab, to monitor inter story drift and modal identification parameters. It was applied to seven high-rise buildings in Dubai and to mosques, museums, suspension bridges, and tall buildings in Turkey.

Cheng et al. [49] carried out the real-time monitoring and ARCH model of 3-story and 8-story buildings using accelerometers, and the results of the experiment were compared with existing results collected from the laboratory. Two indicators, the cepstral metric indicator (CMI) and the second-order variance indicator (SOVI), were compared to identify damage. The SOVI showed a superior output. Rahmani et al. [50] implemented monitoring through experimental and analytical models using MatLab software by adopting time velocity analysis (TVA) for 12-story RC buildings; namely, the Sherman oaks office building, whose dimensions are approximately $18.3 \times 49 \mathrm{~m}$ with a height of $48.5 \mathrm{~m}$. They employed a uniaxial accelerometer. The experiments and analysis indicated that there was a difference in frequency and the average vertical wave velocity after comparing TVA with the analysis of inter-story drift, input power, and instantaneous frequency due to soft soil conditions.

Musafere et al. [51] developed a numerical model for a building with a 5-story shear beam structure and carried out experiments for a 17-story building and a Louis factor building using both sensors and accelerometers. They adopted a blind source separation algorithm under a time-varying autoregressive model and found that this approach is sufficient to predict the dynamic behavior. Yan et al. [52] presented a review on SHM transmissibility function (TF) in buildings with three different categories: modal analysis, modal updating, and damage detection. The results showed that a single input is enough to predict damage using TF.

\section{Static Analysis in SHM of Buildings}

Behnia et al. [53] executed the real-time monitoring of a concrete structure in November 1999 and June 2000 by employing piezoelectric sensors adopting an acoustic emission technique to anticipate damage in terms of frequency, amplitude, severity, cracks, and time domains subjected to static loading conditions, and findings suggested that this method is suitable for the in situ monitoring of a structure. Fortino et al. [54] conducted a laboratory experiment to check the efficiency of Wireless Sensor and Actuator Networks (WASN) to implement SHM for a building management framework. Hackmann et al. [55] demonstrated an FEM using MatLab for a truss and cantilever beam by adopting a damage localization assurance criterion (DLAC) algorithm to keep memory usage, latency, and energy consumption less than $1 \%, 65 \%$, and $64 \%$, respectively.

In Italy, Ierimonti et al. [56] implemented operational monitoring from September 2018 to March 2019 by dividing it into seven intervals for a 3-story RC school building with a height of $16.6 \mathrm{~m}$ by employing nine uni-axial accelerometers using the Bayesian modal updating method for the base-isolated building alone for a static analysis of, e.g., elastic deformation, humidity, and temperature. Carden and Brownjohn [57] carried out real-time monitoring in a 4-story steel building structure with two bays on each side and with dimensions of approximately $2.5 \times 2.5 \times 3.6 \mathrm{~m}$ to detect damage using an accelerometer. They applied a statistical classification algorithm based on an ARMA model and found the prediction of damage to be satisfactory. Wang et al. [58] conducted an experiment and numerical model of a 7-story RC hotel in California by employing an accelerometer to detect the story damage index (SDI) based on system realization using an information matrix (SRIM) technique to predict mode shape and modal frequency.

Kao et al. [5] monitored a 5-story steel building of $3 \times 2 \times 6.5 \mathrm{~m}$. They developed a numerical model by applying an artificial neural network (ANN) to detect static responses, such as displacement, velocity, and acceleration. The results showed that this method helps 
to detect variations in structural properties and generate free vibrations accurately. Ramos et al. [59] carried out monitoring in a Saint Torcato church with towers of approximately $7.5 \times 6.5 \times 50 \mathrm{~m}$, a transept $37 \mathrm{~m}$ in length and $11.5 \mathrm{~m}$ in width, and a central nave that is $57.5 \times 17.5 \times 26.5 \mathrm{~m}$ by employing accelerometer sensors to predict static analysis of, e.g., cracks and vertical deformation. Cracks were monitored by a crack meter, and an FE model was developed by employing TNO Diana software to predict crack and dynamic behavior. Mejri et al. [60] monitored an office building, namely, the Confort Bois construction company - with a total surface area of approximately $110 \mathrm{~m}^{2}$ and a volume of $350 \mathrm{~m}^{3}$ - using $\mathrm{HOBO}$ sensors to measure energy consumption under static parameters such as the heat loss coefficient, utilization factor, and solar aperture.

Bhalla and Soh [61] monitored an RC portal frame of approximately two stories with a height of $2.9 \mathrm{~m}$ and a length of $3.3 \mathrm{~m}$ using a piezoelectric transducer to detect flexural cracks and shear cracks via an EMI technique, and results showed that this technique clearly monitors cracks. Pesci et al. [62] monitored two heritage buildings, namely, the Garisenda tower and the Asinelli building, $48 \mathrm{~m}$ and $97 \mathrm{~m}$ in height, respectively, using an accelerometer employing a terrestrial laser scanning (TLS) technique. An FE model was developed to predict deformation patterns due to gravity and seismic activities. The results showed that the Garisenda tower requires periodical monitoring to protect itself from environmental degradation, and the Asinelli building is not strong enough to withstand seismic activities, so it is necessary to decrease human-made vibrations.

$\mathrm{Xu}$ et al. [63] monitored a 3-story building using sensors to detect damage and isolation bearing properties and suggested the development of a model called bilinear hysteresis, which depends on regression analysis, and results showed that the properties of the superstructure and isolation bearing are less than $6 \%$ compared with the actual model and that this method is applicable only for 2D shear-type frame structures. Saisi et al. [64] carried out real-time monitoring of the bell tower of Italy's Santa Maria del carrobiolo church with a height of $33.7 \mathrm{~m}$ and approximately $5.93 \times 5.70 \mathrm{~m}$ using five temperature sensors and 10 displacement transducers under static loading conditions, and results showed that there is no proper solution to determine abnormal cracking at one time. Only one crack was predicted due to temperature. Butt and Omenzetter [65] practiced monitoring a 3-story building in New Zealand approximately $44.7 \mathrm{~m}$ long, $12.19 \mathrm{~m}$ wide, and $13.40 \mathrm{~m}$ tall, called the GNS Avalon building, using 10 sensors. The FE model was developed by employing Abaqus software. Resonance frequency was less than $7.5 \%$.

Zhang et al. [66] experimented with an aluminum beam with a $136.15 \mathrm{~cm}$ length and a cross section of $2.75 \times 0.3 \mathrm{~cm}$ and developed a numerical model of a 10-story multispan frame and for the same aluminum beam; therefore, three sensors were used for the beams, namely, piezoelectric actuators, and sensitivity analysis and the virtual distortion method (VDM) were adopted. The results indicated that stiffness-related parameters and identification error were less than $8.2 \%$ and $2.9 \%$, respectively. Kane et al. [67] conducted SHM to enhance the impact adopting paradigm shift, which uses more number sensors with lower installation costs and easy-to-collect data; hence, it can be applied to all civil engineering structures, mainly buildings.

Hill-King et al. [68] presented a review of fiber optic strain sensors to practice SHM in many civil engineering structures, including buildings. This worked more effectively to predict damage and structural properties. The results showed that optical fibers are more effective but are more time-consuming for data acquisition compared with electrical strain gauges. Habel [69] experimented with concrete structural elements, such as column and pile foundations approximately $19 \mathrm{~m}$ tall, using two different fiber optic sensors, namely, long-gauge-length fiber optic sensors and short-gauge-length fiber optic sensors, which helped to identify chemical and physical properties and to determine reliability issues. Wang et al. [70] monitored two 12-story buildings (twin towers) in China for approximately 12 months; one building was built using natural-aggregate concrete (NAC) and the other was built using recycled coarse aggregates (RCAs) by employing acceleration sensors, angle 
sensors, and strain sensors to predict wind speed, ambient temperature, and structural response amplitude. The results showed that:

- Frequency increases when ambient temperature increases;

- There were $2.20 \%$ and $1.80 \%$ increases in the recycling aggregate concrete (RAC) structures;

- There were $2.03 \%$ and $0.76 \%$ increases in the frequency for NAC;

- There were $12.60 \%$ and $11.70 \%$ reductions in the damping ratio for RAC and NAC.

Bulajić et al. [71] developed a two-layer shear beam model to analyze a 12-story building above ground level in north Macedonia subjected to 11 earthquake events in the last 25 years, and significant stiffness variations of approximately $19 \%$ to $23 \%$ occurred during the Gnjilane earthquake in 2002, so damage occurred due to non-structural elements. Ayyildiz et al. [72] experimented with carbon fiber reinforced polymer concrete columns to detect damage and fractures of the column using piezoelectric sensors (PZTs) and provided satisfactory results. Jang et al. [73] proposed the design of wireless sensor technology to practice monitoring in buildings; three levels, i.e., new hardware, an open-source operating system for communication, and data acquisition, were developed to enhance monitoring.

Yang and Huang [74] demonstrated a new technique, namely, sequential non-linear least-square estimation (SNLSE), to replace old techniques such as least square estimation (LSE) and the estimated Kalman filter (EKF) to monitor a five-degree-of-freedom non-linear hysteretic building model and a 3-story steel frame FEM, this it helped to reduce the number of sensors needed to detect vibration and damage. Findings showed that the LSE is accurate and reliable.

\section{Dynamic Analysis in SHM in Buildings}

Ivanovic et al. [75] monitored a 7-story RC hotel building with dimensions of $62 \times 150 \mathrm{ft}$ in California using a range seismometer and a transducer to anticipate two ambient vibration surveys on 4 and 5 Feb 1994 as well as 19 and 20 Apr 1994 to detect vertical, transverse, and longitudinal deformations. Jin et al. [76] presented a comparison of PCA in two different approaches called adaptive principal component analysis (APCA) and conventional principal compound analysis (CPCA) to practice SHM, and results indicated that APCA provides superior results since it detects intrinsic behavior and time consumption. Chang et al. [77] experimented with a twin-tower-scaled model that was $1.17 \mathrm{~m}$ tall, $1.50 \mathrm{~m}$ wide, and $1.50 \mathrm{~m}$ deep using an accelerometer and a developed numerical model for the 7-story building to predict dynamic behavior such as natural frequencies and mode shape using OMA based on a neural network, and this helped to predict stiffness reduction in the building. The results showed that this method only applies to a single damaged column, not for multiple-damage conditions.

Pham et al. [78] proposed an optimization algorithm to solve inverse problems in the dynamic analysis of SHM. Dynamic characteristics such as natural frequency and mode shapes have been used to develop mathematical models that measure damage using modal parameters. In this research, a differential evolution algorithm was adopted to evaluate the structural modal parameters. The results showed that this method reduces computational effort and costs, so that uneconomical inverse problems can be avoided. Yuan et al. [79] discussed the mathematical inverse problem and performed automated damage detection for the dynamic modeling of beam structures by adopting machine learning algorithms, and this showed effective results, so there is great potential in real-time monitoring of SHM in future.

Kyriacou et al. [80] demonstrated a new toolbox called contaminant monitoring in a building (COMOB) based on MatLab software to monitor the Holmes house and divided it into 14 zones for sensor placement and to allow for input to the software. As per the results, this approach requires excess data for the software and is applicable for multiple-zone buildings. Nguyen et al. [81] demonstrated a new, cost-effective DAQ technique for the long-term monitoring of institution buildings in Australia and developed a numerical model by adopting vibration sensors, acoustic emission sensors, and accelerometers, and this provided satisfactory results. Yi et al. [82] presented a review to analyze sensor fault 
types, namely, precision degradation, drift, bias, gain, complete failure-1 (constant), complete failure-2 (constant with noise), and complete failure-3 (bottom noise). The detection of sensor faults was carried out via PCA, and it was found that these kinds of sensors fault will occur on tall buildings due to non-linearities. Todorovska and Trifunac [83] monitored a 6-story ICS building with dimensions of approximately $41.70 \times 26.02 \mathrm{~m}$, with a height of $25.48 \mathrm{~m}$, using the triaxial accelerometer, and the monitoring data revealed that significant damage occurred in the first story column at the east end due to the inter-story drift, which exceeded $1.5 \%$, and Gabor transform provided greater control over frequency resolution. Oh et al. [84] carried out monitoring in a high-rise building and conducted a wind tunnel test using Fiber Bragg Grating (FBG) sensors to predict dynamic behavior by adopting a radial basis function neural network (RBFN) based on a genetic algorithm. The results showed that the rigidity of the structure is weak in the wind direction, so it may cause maximum strain. Figure 5 shows the behavior of a multi-story building subjected to dynamic loading conditions.
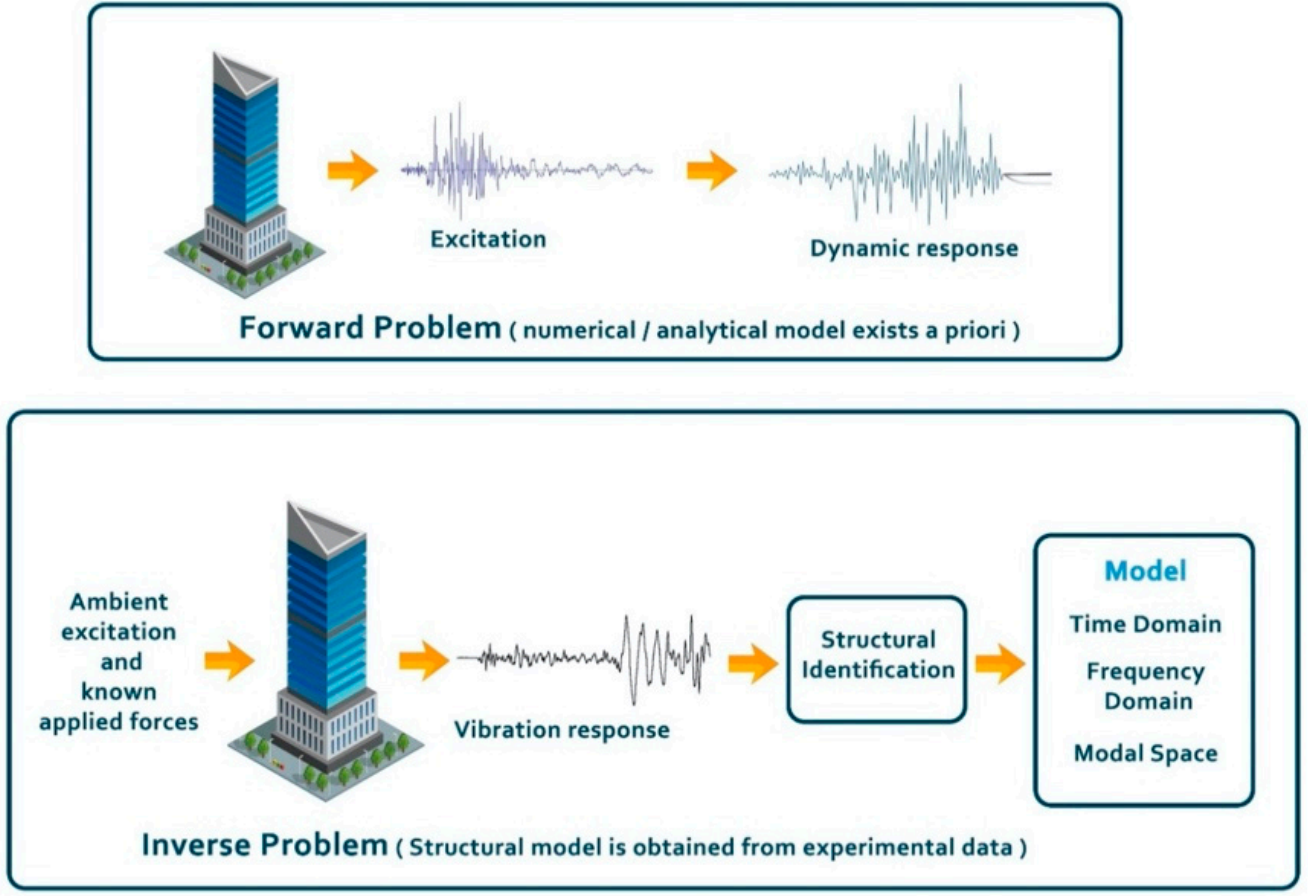

Figure 5. Dynamic response of a multi-story building using SHM.

Celebi et al. [85] experimented with a 30- to 40-story flexible building using steel bars and the real-time monitoring of a 44-story building by fixing GPS in the roof area, and results indicated that the GPS method provides more accurate results than the accelerometer in finding the relative displacement. Pisello et al. [86] monitored the inside of a university building using various sensors to predict the occupants' comfort zone and carried out a real-time survey. Theiler and Smarsly [87] developed a prototype of a 4-story shear frame structure in the laboratory and used assumptions of the BIM to collect monitoring data by adopting the Industry Foundation Classes (IFC) approach, and the results in terms of effective data transfer and data management were satisfactory.

Chen and $\mathrm{Xu}$ [88] conducted an experiment in a 5-story shear building using an accelerometer to analyze the semi-active friction dampers by adopting a local feedback control strategy with and without a Kalman filter, and results showed similar seismic responses both with and without a Kalman filter. Haque et al. [89] developed a new approach, namely, the hybrid topology scheduling algorithm, to anticipate a transmission control mechanism (TCP), and it provided superior output. Alonso et al. [90] presented a review on middleware based on a wireless sensor network (WSN) to protect sensors 
from a monitoring infrastructure called critical protection infrastructure (CPI), and the middleware was very user-friendly for maintenance and programming.

Pingue et al. [91] carried out real-time monitoring and experiments on a 2-story masonry structure that was $10 \mathrm{~m}$ long, $8.5 \mathrm{~m}$ wide, and $8.5 \mathrm{~m}$ tall using FBG for the experiment and geodetic monitoring for the field to predict change instabilities due to ground deformation and concluded that FBG-based investigation provides satisfactory results in the elastic phase, but the data were not easy to understand. Ma et al. [92] demonstrated a new technique called multi-dimensional SAR tomography to monitor and image the creep and shrinkage in concrete of newly constructed two buildings with an approximately, B1 $=500 \mathrm{~m}$ height and B2 $=250 \mathrm{~m}$ height, respectively. The investigation revealed that wall deflection, wall shortening, and thermal expansion were prevented.

Zapico and Gonzalez [93] developed a method for seismic damage identification for buildings with a steel moment-frame structure. To obtain the needed data, they used a simplified numerical model of a 4-story office building of approximately $16 \times 18 \mathrm{~m}$ and 2story heights of 3 and $4 \mathrm{~m}$. This method consists of the following three steps: calibrating the initial stiffness of the structure, continuous monitoring of the live mass, and the subsequent calibration of the final stiffness after a severe earthquake. The frequency coefficient error should be less than $0.5 \%$ so that the damage prediction ratio is $95 \%$ precise. Park and Oh [94] developed a pseudo-frame model of a 123-story tall building under construction called the Lotte world tower, in Korea, to investigate the damping ratio and the modal shape by adopting visual modal identification. Strain gauges, an accelerometer, and an anemometer were used. The results indicated that field monitoring is necessary to predict exact data since this system is not sufficient to extract high-order modal data.

Fujino et al. [95] presented a review on buildings and bridges in Japan subjected to vigorous activities such as a seismic isolation system, damage detection, structural retrofit, and structural assessment. Findings suggested that sensors should be more robust and capable of excess usage, and wireless sensors were preferred for effective monitoring of a more massive structure. He et al. [96] experimented on a 5-story building model with a height of $1750 \mathrm{~mm}$ using three magneto rheological (MR) dampers for vibration control and health monitoring and found satisfactory results. Gao et al. [97] implemented on-site monitoring of a $335 \mathrm{~m}$ tall building with several floors using 128 vibrating wire strain gauges, temperature sensors, and accelerometers and developed an FEM for the building by employing Midas software; they concluded that there will be a decrease in elastic modulus greater than $20 \%$ due to the low quality of concrete and that deformation will hence increase approximately $20 \%$ more than predicted. Furthermore, relative humidity should be checked before constructing a tall building.

Saadat et al. [98] demonstrated two new methods to monitor civil structures, namely, intelligent parameter varying (IPV) and system identification techniques, to anticipate non-linear and non-modal based approaches, and IPV showed superior results compared with the conventional wavelet analysis method. Masciotta et al. [99] practiced monitoring in a Saint Torcato church in Portugal, approximately $58 \mathrm{~m}$ in length and $11 \mathrm{~m}$ in width, with an on-site campaign including visual inspection, geometric surveys, damage diagnosis, control and monitoring using a crack meter, a tiltmeter, and temperature sensors. An accelerometer and a combined sensor as per the results occurred due to the differential soil settlement damage at this building. Karapetrou et al. [100] monitored an 8-story AHEPA hospital located in Thessaloniki by separating it into two units, one being $29 \times 16 \mathrm{~m}$, and the other one being $21 \times 27 \times 16 \mathrm{~m}$, with an inter story height of $3.4 \mathrm{~m}$, by employing 18 sensors. A time building-specific fragility curve was generated and compared with the time-dependent curve to predict seismic vulnerability and the developed FE model. As per the results, the time building-specific fragility curve outperformed the conventional methods in terms of material properties, structural detailing, and mass distribution.

Lorenzoni et al. [101] monitored two heritage building for approximately three years, namely, a Conegliano cathedral and a Roman Amphitheatre (arena), using 16 single-axis piezoelectric accelerometers and displacement transducers integrated with 
humidity/temperature sensors, and significant damage identification results were found. Fan et al. [102] investigated a new TV tower in Guangzhou that was $604 \mathrm{~m}$ tall and 32 stories using various sensors such as accelerometers, strain gauges, and approximately 600 sensors of other types by adopting a residual convolution neural network (ResNet) approach based on vibration signals. Egidio et al. [103] dealt with a perturbation approach for dynamic analysis to predict the mode shapes and natural frequencies to monitor a 4-story shear frame. The damage of the columns was identified by considering random parameters as linear in the numerical analysis. A successful outcome was evident by the very slight errors in anticipating natural frequency [103]. Moreover, Egidio et al. [104] carried out similar uncertainty studies in simply supported beams to predict dynamic behavior adopting random stiffness parameters. Linear operation perturbation theory has been discussed using multiple mathematical solutions [105,106]. Sondipon et al. [107] presented a dynamic system of linear damping concerning the rate of change in eigenvectors and eigenvalues. An expression was derived to demonstrate a damped two degrees of freedom.

Park et al. [108] adopted two approaches based on vision-based displacement, such as the partitioning method and laser displacement sensors, to anticipate the horizontal displacement in a steel column structure for a high-rise building using two webcams and found a $0.5 \%$ difference when comparing the two approaches. Trifunac et al. [109] experimented with a 7-story RC building with dimensions of $62.7 \times 150 \mathrm{ft}$, with a height of $65.7 \mathrm{ft}$, located in Los Angeles using various sensors, and the experiment showed repeated damage on the same spot several times, while an undamaged spot remained the same due to changes in the non-linear stiffness in the soil pile foundation.

\section{Finite Element Analysis in SHM}

Shih et al. [110] developed a dynamic computer simulation technique to assess damage in flexural members such as beams and plates in buildings by adopting two multi-criteria methods, namely, modal strain energy and the modal flexibility method. They experimented and demonstrated an FEM using SAP2000 for three beams, two continuous and one simply supported, by employing an accelerometer to predict building damage. Findings suggested that these two methods provide similar results for single damage, whereas multiple damage is more complicated, so further research is necessary on multiple-damage conditions. Cabboi et al. [111] carried out real-time monitoring and FEM analysis by employing strand software on a heritage building called the San Vittore bell tower with a $37 \mathrm{~m}$ height located in Italy using a piezoelectric accelerometer. PCA was applied to remove fluctuations due to environmental variations; as a result, a $10 \%$ reduction in stiffness was found.

Lautour and Omenzetter [112] demonstrated a non-linear FEM and seismic vulnerability curve along with the ANN approach to model the 2D-RC frame building; however, only one parameter was enough to anticipate ground motion using a seismic vulnerability curve. The results suggested that an ANN provides a superior output when predicting seismically induced damage because it provides output for both structural motion and ground motion compared with the seismic vulnerability curve. Isidori et al. [113] developed a prototype and an FEM of a 3-story building using MEMS sensors and a linear accelerometer to spot the distribution, occurrence, and rise of local damage and to estimate global damage. The FEM model was developed under two different conditions, including distributed plasticity, and was based on lumps to predict the local and global damage of the buildings. The experiment showed that the natural frequency was similar to that of the real structure, but the behavior of the damage seemed different.

Kaneko et al. [114] experimented with a substantial column and a weak beam moment frame in a 6-story structure using two sensors to identify the severity of damage by adopting a damage detection technique. Pushover analysis was carried out to predict shear-related displacement characteristics and its level of damage on each story. Moreover, two-dimensional non-linear FE analysis was carried out by employing ATENA software. As a result, correlations were found between the rotation angle of the column and the level 
of the damage in the heavy deformation stage. Monavari et al. [115] developed an FEM by employing MatLab software on 3-story and 20-story RC frames to spot deterioration in buildings. The analysis accurately showed minor deterioration pre-damage conditions. Enhancement of this method is mandatory when it comes to extreme levels of noise.

Leng et al. [116] experimented with the plane and composite wrap cylinder by using previously found FEA values based on the strain transfer efficiency of a fiber optic sensor protection system. FBG and extrinsic Fabry Perot Interferometric (EFPI) sensors are used for cylinders, but FOS sensors provide superior results compared with electrical resistance strain gauges, so it can be used for smart buildings.

\section{Damage Diagnosis in Buildings}

Rahmani and Todorovska [117] as well as Yuen and Kuok [118] suggested two algorithms, namely, time shift matching (TSM) and non-linear least square fit (LSQ) based on robust interferometry, to monitor a 9-story Millikan library approximately $21 \times 23 \mathrm{~m}$ with a $43 \mathrm{~m}$ height located in California using multiple networks of sensors, and monitored a 22-story hall in East Asia with a height of $64 \mathrm{~m}$ using accelerometers by adopting a Bayesian spectral density approach for approximately one year to predict modal frequency; relative humidity and ambient temperature are necessary for the long-term monitoring of buildings.

Smarsly and Law [119] developed an onboard agent to embed into a wireless sensor to enhance the communication between buildings and the data receiving spot. As per the monitoring, the output derived a $96 \%$ reduction in power consumption and a $95 \%$ reduction in memory utilization. Picozzi [120] demonstrated an earthquake early warning system (EEWS) based on the analysis of P-waves by examining an area in Italy and adopting a tailormade earthquake early warning (TEEW) process. This process consisted of four stages:

- Event characterization by employing an accelerometer;

- Pre-processing P-wave signals;

- The evaluation of predicted shaking;

- Deciding whether to declare alarm or not.

The results showed that the EEWS is suitable for a real-time process for time consumption. Villalba et al. [121] experimented with a concrete slab size, approximately $5.6 \mathrm{~m}$ in length, $1.60 \mathrm{~m}$ in width, and $0.285 \mathrm{~m}$ in thickness, to spot cracks using optical backscatter reflectometer (OBR) sensors. An OBR helps to monitor strains continuously, can be easily placed on the concrete surface, and helps to detect microcracks $1 \mathrm{~mm}$ or smaller. White [122] demonstrated a linear three-dimensional elasticity model for asymmetric building structures with data collected through experiments to anticipate the behavior of structures based on the inversion problem. Severino et al. [123] developed a prototype using COTS hardware to monitor a WSN in a physical infrastructure, and it was reliable and cost-effective.

Yang et al. [124] examined the shear building model with four degrees of freedom based on Hilbert Huang spectral analysis to analyze the damping and stiffness in preand post-damage. The analysis helped to identify damage and stiffness reductions in linear structures effectively. Lee et al. [125] suggested an integrated building fire safety (IBFS) system to improve the automated technology in high-rise residential buildings to avoid false alarms and other undesirable activities, and this provided satisfactory reports by ignoring the monitoring. Reaction durations of fire emergencies were reduced by approximately $63 \%$.

Chase et al. [126] demonstrated the benchmark problem for ASCE with 4-degree-offreedom and 12-degree-of-freedom structures by adopting an undamaged model matrix and a stiffness matrix that comes under the recursive least square (RLS) to monitor damage levels using structural parameters. RLS showed accurate outputs and variations. It requires less than $1.6 \mathrm{~s}$ for all cases and is suitable for real-time monitoring. Unzu et al. [127] implemented real-time monitoring for approximately one year on a telecommunication tower based on an alveolar polycarbonate structure by integrating 31 fiber optic sensors 
with a fiber optic accelerometer and six KNX sensors to predict reliability, mechanical properties, and thermal properties; results showed that it helped to bear thermal and mechanical stresses in a glass panel in a façade system.

$\mathrm{Xu}$ et al. [128] developed a two-scale model of a 12-story main building approximately $2400 \mathrm{~mm}$ in height, with a $184 \mathrm{~mm}$ floor height, and a 3-story podium structure approximately $600 \mathrm{~mm}$ in height, with a $168 \mathrm{~mm}$ floor height, using 16 charge amplifiers, 15 accelerometers, and a current eddy sensor and by adopting a frequency response function (FRF) to anticipate building damage. As per the results, the FRF curve is precise with respect to damage occurrences in connections and provides satisfactory results in terms of identifying the location and the severity of damage, even when the scope of the damages is greater than 5\% and there is noise. Täljsten and Carolin [129] experimented with a $4.5-\mathrm{m}$-long beam in a laboratory using speckle pattern analysis to predict plate bonding to repair and strengthen $\mathrm{RC}$ building elements.

Zhang et al. [130] suggested two algorithms, namely, the probability density evolution equation (PDEE) based on the reliability evolution method and the statistical momentbased system identification method (SMB), for predicting reliability evaluations and system identifications in a building with data received from a 2-story stochastic shear building model with three damage events: a single damage on the second story and multiple damages on the first and third stories. The results showed that, when the threshold increases, reliability increases. Yu et al. [131] investigated the power monitoring system in buildings using the Internet of Things (IoT) to resolve the monitoring object location and the placement, and this helped to predict the voltage curve with the help of a display interface.

Su et al. [132] developed a 6-story shear building model and a 5-story, steel-frame non-sheer building model using accelerometers and adopted wavelet transform techniques to measure the damage in each story using sub-structural frequencies. The results showed that a decrease in natural frequencies of the severe damage found in 6-story buildings and variation in mass or stiffness damage in the first story of the 5-story steel frame. Burnett et al. [133] investigated an electrical distribution system found in high-rise buildings, which generates an extremely low-frequency magnetic field (ELF), and it creates several health problems when it interferes with sensing equipment, so using more bus ducts can reduce these problems.

Grinzato et al. [134] carried out real-time monitoring in a historic building located in Venice's arsenal using IR thermography to monitor moisture content, finishing status, and the hidden structure of walls, and mutual interaction differs due to various environmental factors and becomes challenging. This was found to be successful for thermal diffusivity, moisture mapping, and wall bonding. Tanet al. [135] experimented with steel bars to make full use of FBG sensors for monitoring purposes. FBG sensors were provided with a coating, such as a polydimethylsiloxane strain-sensitive coating or a $\mathrm{pH}$-sensitive hydrogel adopting the Bragg wavelength method. The steel rod underwent three different tests by exposing it to air, acid, and alkaline, and a higher sensitivity was found in an acidic environment. These methods are only applicable for laboratory monitoring purposes, so further research on real-time monitoring is necessary.

Kruger [136] presented a review of wireless sensor systems in concrete buildings to demonstrate the design, concepts, and sensor requirements of short- and long-term monitoring. As per the results, data interpretation and data analysis are mandatory to analyze the nature of a building. Using intelligent data processing is more costly than conventional cable monitoring systems. Madan [137] introduced a new technique to anticipate earthquake-induced vibrations in buildings, using a counter propagation network (CPN), without considering target control forces. This technique was applied to an 8-story building for monitoring. Furthermore, the CPN was compared with the backpropagation neural (BPN) network, and the CPN provided a more satisfactory output in terms of time consumption, reliability in taking large data, and trainability.

Boutet et al. [138] developed a prototype of a school building in Argentina during June 2012 to predict thermal and hygro-thermal lighting behavior during the autumn season 
using $\mathrm{HOBO}$ sensors, and results showed an illuminance level up to $4001 \times$ on average. It saved in terms of electrical consumption, due to the use of natural light. De Wilde and Coley [139] presented a review on building responses due to climatic impact, so the history of collected data was considered for monitoring and other purposes, and occupants' thermal comfort were taken into account due to climatic changes. Jiang et al. [140] investigated a 7-story shear beam model using multiple sensors by adopting a fuzzy neural network (FNN) and data fusion techniques using fusion algorithms. As per the findings, damage identification can be made in the initial stage, and damage assessment can be conducted in the second stage. More experiments are necessary for real-time monitoring; as of now, it can be only be applied to numerical simulation. Kim et al. [141] investigated a plate girder approximately $24,500 \mathrm{~mm}$ in length and a beam in a building under construction, namely, the K Art Hall, using vibrating wire strain gauges (VWSGs), and results suggested that complicated wire connections can be neglected and are easy to maintain, and tensile stress was more than $6 \%$ due to variations in the stress in long-span girders.

Hajdukiewicz et al. [142] carried out real-time monitoring in two educational buildings, the Institute of Life Course and Society (ILCS) building and the Engineering Building (EB), as suggested by the National University of Ireland, using various gauges and sensors. Once the continuous monitoring in a building is safe, improved indoor environments and energy consumption follows, so energy efficiency measures are necessary to reduce the environmental impacts on buildings. Liet al. [143] presented an overview of fiber optic sensors used for SHM in buildings, including distributed fiber optic sensors, local fiber optic sensors, and quasi distributed sensors, and results showed that an FOS will play a crucial role in the future of SHM in buildings.

Bakis et al. [144] experimented with seven hybrid fiber-reinforced polymer rods to predict the pseudo ductility and the self-monitoring capability using piezo resistivity, and early catastrophic failure was observed. Hiromi et al. [145] studied the SHM application in a 5-story building adopting an SVM based on a machine learning technique under modal frequencies using two vibration sensors. The SVM helped to detect multiple damages in multi-story buildings. Naet al. [146] developed a 20-story shear beam model using sensors by implementing genetic algorithms using a flexibility matrix based on a damage evaluation method and developed numerical simulations using OpenSees software. This yielded excellent reports, even with inadequate data, and modal mass was exceeded by approximately $90 \%$ due to the genetic algorithm.

Zhang et al. [147] demonstrated a support vector regression (SVR) approach using 52 degrees of freedom and 30 degrees of freedom by applying an SVR training algorithm, and findings showed that SVR provided accurate and robust data for long-term monitoring on a large scale, even when contaminated by noise. Cataldo et al. [148] suggested a method known as time-domain reflectometry (TDR) using a passive, diffuse sensing element (SE) that looks like a wire to monitor the rising damping in the building structure. The SE was permanently embedded into a wall when the building was under construction or renovation to monitor the behavior of the wall, and it was concluded that this method not only monitors moisture content inside the wall [149], but also the overall health status of the building [148].

Ni et al. [150] carried out real-time monitoring in a structure using accelerometers and temperature sensors and by implementing SVM techniques to predict temperature effects. Kopsaftopoulos and Fassois [151] experimented on an aluminum truss with overall dimensions of approximately $1400 \times 700 \times 800 \times 700 \mathrm{~mm}$, using strain gauges and implanting a time series method to diagnose the building's damage. Nonparametric and parametric methods yielded effective outputs for the time series method to detect global or local damage and precisely predict actual damage [151,152]. Huang et al. [153] adopted an Autoregressive and an ANN model to predict variations in temperature to carry out a vibration-based damage identification process. FE models were used to demonstrate the reliability and effectiveness of this method. The American Association of Civil Engineers (ASCE) benchmark model and an FE model using SAP 2000 was adopted. The results 
indicated satisfactory outcomes by predicting temperature variation and noise disturbances according to the numerical results. Huang et al. [154] experimented with a two-span steel gird and three-span continuous beam. They used a model-based damage identification method by adopting a genetic algorithm approach to optimize the solution and assumed mode shapes and natural frequencies to predict the variations in temperature and noise. The FE model was developed with MatLab software, and findings were positive for 3, 5, 10,20 , and $30 \%$ of the mode shapes with a feasible range in a noise environment [154]. Huang et al. [155] adopted a hybrid algorithm, known as PSO-CS, a combination of particle swarm optimization (PSO) and cuckoo search (CS), to anticipate temperature and noise. The main objective was to find the elastic modulus variation due to the temperature effect using an FE model of the ASCE benchmark model, and MatLab software was employed for beam and frame structures. The outcome of the research using PSO-CS, monitoring almost all possible damages, showed an outstanding performance [155,156].

Huang et al. [157] used frameworks such as modal flexibility, enhanced moth-flame optimization, and modal frequency strain energy assurance criterion (MFSEAC) for the identification of damages in structures. Findings showed that the enhanced moth-flame optimization provided superior outcomes compared with particle swarm optimization, CS, and moth-flame optimization. Three numerical samples, such as 40 -story shear frames with irregular noise, 31 bar truss structures with irregular temperature and noise, and three-span concrete that continued to beam with variations in temperature, were compared by the adopting modal assurance criterion (MAC), modal strain energy (MSE), modal flexibility, and the frequency change ratio (FCR). In addition, two laboratory samples were used to verify the outcome, and satisfactory results with substantial effects were found along with positive noise robustness [157]. Appendix A represents list of reviewed buildings with SHM implemented.

\section{Comparative Study and Future Recommendations}

A critical analysis of methodologies adopted to monitor buildings using various sensors was performed. Best-practice sensors were classified based on previously published literature. The findings suggest that accelerometers are used to monitor buildings much more widely than other sensors are. Accelerometers provide superior outcomes for static and dynamic analysis. Table 1 displays the role of various other sensors compared with accelerometers.

This article compares accelerometers with other sensors to monitor buildings. It is clear that accelerometers perform well in dynamic analyses and less effectively in static analyses. To solve this issue, we suggest a combination of sensors, such as strain gauges, FBGs, HOBOs, displacement transducers, temperature sensors, piezoelectric sensors, and IR thermography, with accelerometers. The SHM of buildings will increase in terms of various parameters such as cracks, indoor environments, displacement, strain, temperature, humidity, and elastic deformations.

In the present scenario, recommendations for future purposes are necessary to increase the overall efficiency of research to produce precise and quick data collection. Based on the detailed discussion of previously reported works, the following points must be considered to enhance research on the SHM of buildings [13,46,53]:

- Development is necessary to enhance the life span of sensors and their data transformations for long-term monitoring purposes; hence, advanced sensors should be designed with a high sensitivity and range.

- The prediction of damage should be implemented in various environmental activities, so that monitoring can be executed in buildings to an even greater extent.

- To improve consistency, DAQ and predictive analysis are needed to maintain communication between buildings and sensors for both short-term and long-term monitoring.

- A greater understanding of instrumentation, mathematical techniques, and signal processing is essential to understand the behavior of buildings in terms of monitoring and predicting damage. 
- Further research is mandatory to practice SHM at low cost, especially for wireless communication.

A robust statistical method should be considered when measuring the static and dynamic response of buildings.

Table 1. Role of various sensors compared with accelerometers.

\begin{tabular}{|c|c|c|}
\hline No. & Accelerometer in SHM & Other Sensors Used in SHM \\
\hline 1 & $\begin{array}{l}\text { Accelerometers perform more effectively } \\
\text { in a smaller number of sensors. }\end{array}$ & $\begin{array}{c}\text { In other sensors, a greater number of } \\
\text { sensors is needed. }\end{array}$ \\
\hline 2 & $\begin{array}{l}\text { Accelerometers help to predict damage in } \\
\text { beam-column joints more effectively, } \\
\text { with an } 85 \% \text { accuracy. }\end{array}$ & $\begin{array}{c}\text { In other sensors, the choice of } \\
\text { assessing beam-column joint was } \\
\text { occasional, and the level of accuracy } \\
\text { was not as high. }\end{array}$ \\
\hline 3 & $\begin{array}{l}\text { The level of frequency and deformation } \\
\text { can be predicted with } 90 \% \text { accuracy in } \\
\text { accelerometers. }\end{array}$ & $\begin{array}{l}\text { Optical fiber sensors alone can } \\
\text { perform equally to accelerometers to } \\
\text { predict the frequency level; however, } \\
\text { other sensors show a lower accuracy. }\end{array}$ \\
\hline 4 & $\begin{array}{l}\text { Accelerometers, based on MEMS } \\
\text { technologies, cooperate in assessing } \\
\text { damage using wave propagation } \\
\text { algorithms. }\end{array}$ & $\begin{array}{c}\text { Other sensors do not have such } \\
\text { advanced technology to assess } \\
\text { damage. }\end{array}$ \\
\hline 5 & $\begin{array}{l}\text { Model identifications and ambient } \\
\text { vibrations can be practiced in } \\
\text { accelerometers for a dynamic analysis of } \\
\text { all environmental changes }\end{array}$ & $\begin{array}{l}\text { In other sensors, dynamic analysis } \\
\text { can be predicted by assessing the } \\
\text { vertical deformation and changes in } \\
\text { the building's behavior. }\end{array}$ \\
\hline 6 & $\begin{array}{l}\text { Uniaxial accelerometers adopt TVA to } \\
\text { carry out real-time monitoring using an } \\
\text { analytical model and experimental data. }\end{array}$ & $\begin{array}{l}\text { TVA is not used by other sensors for } \\
\text { monitoring purposes. }\end{array}$ \\
\hline 7 & $\begin{array}{c}\text { Accelerometers poorly identify flexural } \\
\text { cracks, shear cracks, amplitude, and time } \\
\text { domains. }\end{array}$ & $\begin{array}{l}\text { Piezoelectric sensors are better able to } \\
\text { detect cracks, amplitude, and time } \\
\text { domains, with a } 75 \% \text { accuracy. }\end{array}$ \\
\hline 8 & $\begin{array}{l}\text { Accelerometers outperform other sensors } \\
\text { in dynamic analysis but show a limited } \\
\text { response in static analysis, e.g., for } \\
\text { temperature, humidity, or deformation }\end{array}$ & $\begin{array}{c}\text { Temperature sensors, displacement } \\
\text { transducers, and FBGs outperform } \\
\text { accelerometers in anticipating } \\
\text { temperature, humidity, or } \\
\text { deformation }\end{array}$ \\
\hline 9 & $\begin{array}{l}\text { Accelerometers show a lack of efficiency } \\
\text { in monitoring a wall's hidden structure, } \\
\text { moisture content, hygrothermal behavior } \\
\text { during the autumn season, energy } \\
\text { consumption, and indoor environments. }\end{array}$ & $\begin{array}{l}\text { Vibrating wire strain gauges, HOBOs, } \\
\text { IR thermography, or KNX effectively } \\
\text { monitor a wall's hidden structure, } \\
\text { moisture content, hygrothermal } \\
\text { during the autumn season, energy } \\
\text { consumption, and indoor } \\
\text { environments. }\end{array}$ \\
\hline 10 & $\begin{array}{c}\text { Accelerometers do not monitor stress, } \\
\text { strain, temperature, cracks, or humidity } \\
\text { well. }\end{array}$ & $\begin{array}{l}\text { Other sensors such as strain gauges, } \\
\text { temperature sensors, FBGs, piezo } \\
\text { electric sensors, and displacement } \\
\text { transducers provide satisfactory } \\
\text { outcomes compared with } \\
\text { accelerometers. }\end{array}$ \\
\hline
\end{tabular}

\section{Conclusions}

This review discusses the building structural health monitoring of all parameters using static, dynamic, and finite element methods to detect or predict building damage. The whole structural health monitoring consists of four characteristics: the presence, location, and severity of the damage and the remaining service life of the building after damage. 
The article discusses the important approaches, processes, hardware, and sensors adopted for SHM in buildings. The following claims can be made:

- Currently available techniques can be used to implement SHM in buildings along with efforts made to enhance the technique both economically and practically for monitoring purposes.

- The Bayesian approach for SHM in buildings can predict damage and deterioration and to evaluate the variation in dynamic structural properties.

- Numerical models in SHM using Matlab, OpenSees, and other, similar software can help to determine structural responses adopting various algorithms.

- Damage severity can be predicted in the initial stiffness using piezoelectric sensor patches and electro-mechanical impedance techniques by acquiring a global dynamic technique, and medium to severe damage can be extracted through monitoring with utmost accuracy.

- The SHM approach is extremely suitable for real-time monitoring if the methods are carried out comfortably by precisely applying all techniques.

- Ambient vibration methods range from measured dynamic responses to real-time monitoring such as mode shapes, modal damping ratios, and natural frequencies.

- Various types of sensors are used for structural health monitoring such as fiber optic sensors, piezoelectric sensors, microelectromechanical system sensors, accelerometer, temperature sensors, and accelerometers.

- Predictive analysis and data acquisitions can be applied to buildings using sensors, so sensors inputs are safe and reliable in accordance with building conditions.

- SHM can be applied for different types of buildings, including multi-story buildings, commercial buildings, and heritage buildings, and various works have been discussed in detail.

- The static and dynamic behavior of buildings can be used to predict damage at an early stage by adopting SHM techniques along with finite element analysis reports.

- The in-detail analysis of software, hardware, and real-time data along with future perceptions are based on the operating principles for SHM in buildings.

Author Contributions: Conceptualization, A.S., D.S.V., M.D.V. and E.K.; methodology, A.S., D.S.V.; validation, W.G., Ł.W., M.D.V. and E.K.; formal analysis, M.D.V., E.K.; investigation, A.S., D.S.V.; data curation, A.S., D.S.V., W.G., Ł.W. and E.K.; writing—original draft preparation, A.S.; writing—review and editing, M.D.V., E.K.; visualization, A.S., D.S.V.; supervision, M.D.V. All authors have read and agreed to the published version of the manuscript.

Funding: This research received no external funding.

Data Availability Statement: No new data were created or analyzed in this study. Data sharing is not applicable to this article.

Conflicts of Interest: The authors declare no conflict of interest.

Appendix A

Table A1. List of the reviewed buildings with the implemented SHM.

\begin{tabular}{cccccc}
\hline No. & Source by Author & $\begin{array}{c}\text { Subject of Study } \\
\text { (Type of Building) }\end{array}$ & $\begin{array}{c}\text { Number of } \\
\text { Stories }\end{array}$ & $\begin{array}{c}\text { Types of Sensors } \\
\text { Used }\end{array}$ & Measured Parameters \\
\hline 1 & Olivera Lópezet al. [12] & 14 floor building & 14 & $\begin{array}{c}\text { Hydrodynamic forces to } \\
\text { detect the damage }\end{array}$ \\
\hline 2 & $\begin{array}{c}\text { Roghaeiand and } \\
\text { Zabihollah [14] }\end{array}$ & $\begin{array}{c}\text { Hospital steel } \\
\text { structure }\end{array}$ & 3 & $\begin{array}{c}\text { Piezoelectric } \\
\text { sensors }\end{array}$ & $\begin{array}{c}\text { To identify the stress } \\
\text { and deformation }\end{array}$ \\
\hline 3 & Zhouet al. [15] & RC frame building & 12 & $\begin{array}{c}\text { Variation in stiffness } \\
\text { using elastic, hybrid and } \\
\text { pinched }\end{array}$ \\
\hline 4 & Pierdicca et al. [16] & $\begin{array}{c}\text { Concrete school } \\
\text { building }\end{array}$ & - & - & Dynamic behavior of \\
buildings
\end{tabular}


Table A1. Cont.

\begin{tabular}{|c|c|c|c|c|c|}
\hline No. & Source by Author & $\begin{array}{c}\text { Subject of Study } \\
\text { (Type of Building) }\end{array}$ & $\begin{array}{l}\text { Number of } \\
\text { Stories }\end{array}$ & $\begin{array}{c}\text { Types of Sensors } \\
\text { Used }\end{array}$ & Measured Parameters \\
\hline 5 & Demetriou [17] & 3-story building & 3 & - & $\begin{array}{l}\text { Reduction in stiffness } \\
\text { because of harmonic } \\
\text { motion }\end{array}$ \\
\hline 6 & Dong et al. [18] & $\begin{array}{l}\text { Van Nuys hotel and } \\
\text { imperial country } \\
\text { service building }\end{array}$ & - & - & $\begin{array}{l}\text { Relationship between } \\
\text { the severity of damage } \\
\text { and damage index }\end{array}$ \\
\hline 7 & Yanget al. [19] & Steel frame building & 20 & - & $\begin{array}{l}\text { Dynamic behavior due } \\
\text { to seasonal frost }\end{array}$ \\
\hline 8 & Autunes et al. [20] & $\begin{array}{l}\text { Adobe masonry } \\
\text { structure }\end{array}$ & - & $\begin{array}{l}\text { Optical fiber } \\
\text { sensors }\end{array}$ & Natural frequency \\
\hline 9 & Hisonet al. [22] & Tufa wall & - & $\begin{array}{l}\text { Magnetoelastic } \\
\text { sensors }\end{array}$ & $\begin{array}{l}\text { Elastic deformation and } \\
\text { fracture alarm }\end{array}$ \\
\hline 10 & Mahjoubiet al. [23] & Shanghai tower & - & $\begin{array}{c}\text { Triaxial } \\
\text { accelerometer }\end{array}$ & $\begin{array}{c}\text { To reduce the number of } \\
\text { sensors }\end{array}$ \\
\hline 11 & Sajedi and Liang [24] & $\begin{array}{l}\mathrm{RC} \text { moment frame } \\
\text { building }\end{array}$ & 3 & - & $\begin{array}{c}\text { Prediction of damage } \\
\text { location, existence, and } \\
\text { Severity }\end{array}$ \\
\hline 12 & Soltaninejadet al. [27] & Two adjacent building & - & - & Anticipate pounding \\
\hline 13 & $\begin{array}{c}\text { García-Macías and } \\
\text { Ubertini [28] }\end{array}$ & Sciri tower & - & Accelerometers & $\begin{array}{c}\text { Levels of frequency and } \\
\text { deformation }\end{array}$ \\
\hline 14 & Sunet al. (2019) [29] & $\begin{array}{l}\text { Skyscraper building } \\
\text { (Al Harma Tower) }\end{array}$ & 86 & - & $\begin{array}{l}\text { To find the building } \\
\text { deformation due to } \\
\text { heavy dead load and } \\
\text { seismic response }\end{array}$ \\
\hline 15 & Chelliniet al. [30] & $\begin{array}{l}\text { Composite frame } \\
\text { structure }\end{array}$ & & $\begin{array}{l}\text { Accelerometer } \\
\text { sensors }\end{array}$ & $\begin{array}{c}\text { Damage in } \\
\text { beam-column joint }\end{array}$ \\
\hline 16 & Morales-Valdezet al. [31] & 5-story building & 5 & $\begin{array}{c}\text { MEMS } \\
\text { Technologies based } \\
\text { accelerometers }\end{array}$ & $\begin{array}{c}\text { Predict damage by } \\
\text { adopting a wave } \\
\text { propagation algorithm }\end{array}$ \\
\hline 17 & Pachón et al. [33] & $\begin{array}{l}\text { Heritage building } \\
\text { (Monastery of San } \\
\text { Jeronimo de } \\
\text { Buenavista) }\end{array}$ & - & - & $\begin{array}{l}\text { Dynamic behaviour like } \\
\text { ambient vibration and } \\
\text { model identification }\end{array}$ \\
\hline 18 & Frigui et al. [34] & Ophite tower & 18 & - & Damage severity \\
\hline 19 & $\begin{array}{c}\text { García-Macías and } \\
\text { Umbertini [36] }\end{array}$ & Consoli palace & - & $\begin{array}{l}\text { various sensors } \\
\text { types }\end{array}$ & Damage \\
\hline 20 & Li et al. [37] & $\begin{array}{l}\text { Tall building (Ping an } \\
\text { Finance Centre) }\end{array}$ & - & different sensors & $\begin{array}{c}\text { Vertical deformation in } \\
\text { the various structural } \\
\text { element }\end{array}$ \\
\hline 21 & Zhanget al. [38] & 108-story building & 108 & $\begin{array}{l}\text { Accelerometers } \\
\text { and tilt sensors }\end{array}$ & $\begin{array}{l}\text { Monitor and damage } \\
\text { prediction }\end{array}$ \\
\hline 22 & Modenaet al. [39] & $\begin{array}{l}\text { Heritage structures, } \\
\text { Spanish fortress, and } \\
\text { tower (L'Aquila), } \\
\text { Scrovengni chapel } \\
\text { (Padova), the stone } \\
\text { tomb of Cansignorio }\end{array}$ & - & - & $\begin{array}{l}\text { static and dynamic } \\
\text { response of the building }\end{array}$ \\
\hline 23 & Aguilaret al. [41] & Adobe church & - & Accelerometers & $\begin{array}{c}\text { Damage } \\
\text { post-earthquake }\end{array}$ \\
\hline
\end{tabular}


Table A1. Cont.

\begin{tabular}{|c|c|c|c|c|c|}
\hline No. & Source by Author & $\begin{array}{l}\text { Subject of Study } \\
\text { (Type of Building) }\end{array}$ & $\begin{array}{l}\text { Number of } \\
\text { Stories }\end{array}$ & $\begin{array}{c}\text { Types of Sensors } \\
\text { Used }\end{array}$ & Measured Parameters \\
\hline 24 & Coletta et al. [43] & Sanctuary of Vicoforte & - & various sensors & $\begin{array}{c}\text { Dynamic behaviour for } \\
\text { all environmental } \\
\text { degradation }\end{array}$ \\
\hline 25 & Lam et al. [45] & $\begin{array}{c}\text { Boat-shaped building } \\
\text { (Academic building } \\
\text { 3(AC3) }\end{array}$ & $\begin{array}{l}20 \text { main story and } \\
5 \text { adj. story }\end{array}$ & - & $\begin{array}{l}\text { Monitoring for the } \\
\text { changes in the } \\
\text { behaviour of building }\end{array}$ \\
\hline 26 & Lorenzoniet al. [46] & $\begin{array}{l}\text { Cultural heritage } \\
\text { building (Spanish } \\
\text { fortress and tower) }\end{array}$ & - & - & $\begin{array}{l}\text { Robust statistical } \\
\text { method and damage } \\
\text { detection algorithms }\end{array}$ \\
\hline 27 & Kaya and Safak [48] & High rise building & - & - & $\begin{array}{c}\text { Developed new } \\
\text { software REC_MIDS }\end{array}$ \\
\hline 28 & Cheng et al. [49] & 3 and 8-story building & 3 and 8 & Accelerometers & $\begin{array}{l}\text { Real-time monitoring to } \\
\text { identify damage }\end{array}$ \\
\hline 29 & Rahmani et al. [50] & $\begin{array}{l}\text { Sherman oaks office } \\
\text { building }\end{array}$ & 12 & $\begin{array}{c}\text { uniaxial } \\
\text { accelerometer }\end{array}$ & $\begin{array}{l}\text { Monitoring through } \\
\text { experimental and } \\
\text { analytical models by } \\
\text { adopting time velocity } \\
\text { analysis }\end{array}$ \\
\hline 30 & Musafere et al. [51] & $\begin{array}{l}\text { A building with } \\
\text { 17-story and Louis } \\
\text { factor building }\end{array}$ & 17 & $\begin{array}{l}\text { sensors and } \\
\text { accelerometers }\end{array}$ & $\begin{array}{l}\text { To predict the dynamic } \\
\text { behavior }\end{array}$ \\
\hline 31 & Behniaet al. [53] & concrete structure & & $\begin{array}{l}\text { Piezoelectric } \\
\text { sensors }\end{array}$ & $\begin{array}{l}\text { Anticipate damage like } \\
\text { frequency, amplitude, } \\
\text { severity, cracks, and } \\
\text { time-domain }\end{array}$ \\
\hline 32 & Ierimontiet al. [56] & RC school building & 3 & $\begin{array}{c}\text { Uni-axial } \\
\text { accelerometers }\end{array}$ & $\begin{array}{l}\text { Static analysis such as } \\
\text { elastic deformation, } \\
\text { humidity, and } \\
\text { temperature }\end{array}$ \\
\hline 33 & $\begin{array}{c}\text { Carden and Brownjohn } \\
\text { [57] }\end{array}$ & $\begin{array}{l}\text { Steel building } \\
\text { structure }\end{array}$ & 4 & Accelerometer & $\begin{array}{l}\text { Prediction of occurrence } \\
\text { of damage }\end{array}$ \\
\hline 34 & Wang et al. [58] & RC hotel building & 7 & Accelerometer & $\begin{array}{l}\text { Detect story damage } \\
\text { index (SDI) }\end{array}$ \\
\hline 35 & Kao et al. [5] & Steel building & 5 & - & $\begin{array}{l}\text { Detect static response } \\
\text { such as displacement, } \\
\text { velocity, and } \\
\text { acceleration }\end{array}$ \\
\hline 36 & Ramoset al. [59] & Saint Torcato church & & Accelerometer & $\begin{array}{c}\text { Predict static analysis } \\
\text { like cracks and vertical } \\
\text { deformation }\end{array}$ \\
\hline 37 & Mejriet al. [60] & $\begin{array}{c}\text { office building } \\
\text { (Confort Bois } \\
\text { construction company) }\end{array}$ & & HOBO sensors & $\begin{array}{l}\text { To measure energy } \\
\text { consumption }\end{array}$ \\
\hline 38 & Bhalla and Soh [61] & $\mathrm{RC}$ portal frame & 2 & $\begin{array}{l}\text { Piezoelectric } \\
\text { transducer }\end{array}$ & $\begin{array}{c}\text { Detect flexural crack and } \\
\text { shear crack }\end{array}$ \\
\hline 39 & Pesciet al. [62] & $\begin{array}{l}\text { Two heritage buildings } \\
\text { (Garisenda tower and } \\
\text { Asinelli) }\end{array}$ & & Accelerometer & $\begin{array}{l}\text { To predict deformation } \\
\text { patterns due to gravity } \\
\text { and seismic activities }\end{array}$ \\
\hline 40 & Xuet al. [63] & 3-story building & 3 & Sensor & $\begin{array}{l}\text { Detect damage and } \\
\text { isolation properties }\end{array}$ \\
\hline
\end{tabular}


Table A1. Cont.

\begin{tabular}{|c|c|c|c|c|c|}
\hline No. & Source by Author & $\begin{array}{l}\text { Subject of Study } \\
\text { (Type of Building) }\end{array}$ & $\begin{array}{c}\text { Number of } \\
\text { Stories }\end{array}$ & $\begin{array}{c}\text { Types of Sensors } \\
\text { Used }\end{array}$ & Measured Parameters \\
\hline 41 & Saisiet al. [64] & $\begin{array}{l}\text { Bell tower of church } \\
\text { Santa Maria del } \\
\text { carrobiolo }\end{array}$ & - & $\begin{array}{l}\text { Temperature } \\
\text { sensors, } \\
\text { displacement } \\
\text { transducers }\end{array}$ & Real-time monitoring \\
\hline 42 & $\begin{array}{l}\text { Butt and Omenzetter } \\
{[65]}\end{array}$ & GNS Avalon building & 3 & Sensors & $\begin{array}{c}\text { FE model has developed } \\
\text { by employing Abaqus } \\
\text { Software }\end{array}$ \\
\hline 43 & Bulajićet al. [71] & 12-story building & 12 & - & $\begin{array}{l}\text { Damage occurs due to } \\
\text { non-structural elements }\end{array}$ \\
\hline 44 & Ivanovićet al. [75] & RC hotel building & 7 & $\begin{array}{c}\text { Range } \\
\text { seismometer and } \\
\text { transducer }\end{array}$ & $\begin{array}{c}\text { Detect deformations like } \\
\text { vertical, transverse, and } \\
\text { longitudinal }\end{array}$ \\
\hline 45 & Changet al. [77] & Twin tower & - & Accelerometer & $\begin{array}{l}\text { To predict the dynamic } \\
\text { behaviour such as } \\
\text { natural frequencies and } \\
\text { mode shape }\end{array}$ \\
\hline 46 & Kyriacouet al. [80] & Holmes house & - & - & $\begin{array}{c}\text { Demonstrated new } \\
\text { toolbox called } \\
\text { contaminant monitoring } \\
\text { in a building (COMOB) }\end{array}$ \\
\hline 47 & Nguyen and Chan [76] & Institution buildings & - & $\begin{array}{l}\text { Vibration sensors, } \\
\text { acoustic emission } \\
\text { sensors, } \\
\text { accelerometers }\end{array}$ & $\begin{array}{l}\text { Demonstrated new } \\
\text { cost-effective DAQ } \\
\text { technique }\end{array}$ \\
\hline 48 & $\begin{array}{l}\text { Todorovska and } \\
\text { Trifunac [83] }\end{array}$ & ICS building & 6 & $\begin{array}{c}\text { Triaxial } \\
\text { accelerometer }\end{array}$ & $\begin{array}{l}\text { To monitor the damage } \\
\text { occurrence }\end{array}$ \\
\hline 49 & Oh et al. [84] & High-rise building & - & FBG sensors & $\begin{array}{c}\text { Predict dynamic } \\
\text { behaviour }\end{array}$ \\
\hline 50 & Celebi [85] & 44-story building & 44 & & $\begin{array}{l}\text { Monitoring by fixing } \\
\text { GPS }\end{array}$ \\
\hline 51 & Chen and $\mathrm{Xu}$ [88] & Shear Building model & 5 & Accelerometer & $\begin{array}{c}\text { To analyses the } \\
\text { semi-active friction } \\
\text { dampers }\end{array}$ \\
\hline 52 & Pingue et al. [91] & Masonry structure & 2 & FBG & $\begin{array}{c}\text { To predict changes in } \\
\text { instability due to ground } \\
\text { deformation }\end{array}$ \\
\hline 53 & Ma et al. [92] & $\begin{array}{l}\text { Newly constructed } \\
\text { two buildings }\end{array}$ & - & - & $\begin{array}{l}\text { SAR tomography to } \\
\text { monitor and imaging of } \\
\text { creep and shrinkage } \\
\text { occurs }\end{array}$ \\
\hline 54 & $\begin{array}{c}\text { Zapico and Gonzalez } \\
{[93]}\end{array}$ & Office building & 4 & - & $\begin{array}{l}\text { Seismic damage } \\
\text { identification by } \\
\text { adopting ANN }\end{array}$ \\
\hline 55 & Park and Oh [94] & $\begin{array}{l}\text { Tall building (Lotte } \\
\text { world tower) }\end{array}$ & 123 & $\begin{array}{l}\text { Strain gauges, } \\
\text { accelerometer, } \\
\text { anemometer }\end{array}$ & $\begin{array}{l}\text { To investigate damping } \\
\text { ratio and modal shape }\end{array}$ \\
\hline 56 & He et al. [96] & Building Model & 5 & MR dampers & $\begin{array}{l}\text { For vibration control } \\
\text { and health monitoring }\end{array}$ \\
\hline
\end{tabular}


Table A1. Cont.

\begin{tabular}{|c|c|c|c|c|c|}
\hline No. & Source by Author & $\begin{array}{l}\text { Subject of Study } \\
\text { (Type of Building) }\end{array}$ & $\begin{array}{l}\text { Number of } \\
\text { Stories }\end{array}$ & $\begin{array}{c}\text { Types of Sensors } \\
\text { Used }\end{array}$ & Measured Parameters \\
\hline 57 & Gao et al. [97] & Tall building & - & $\begin{array}{l}\text { Vibrating wire } \\
\text { strain gauges, } \\
\text { temp. sensors and } \\
\text { accelerometers }\end{array}$ & $\begin{array}{c}\text { onsite monitoring and } \\
\text { developed FEM }\end{array}$ \\
\hline 58 & Masciotta et al. [99] & Saint torcato church & - & $\begin{array}{l}\text { Crack meter, } \\
\text { tiltmeter, } \\
\text { temperature } \\
\text { sensors. } \\
\text { accelerometer and } \\
\text { combined sensor }\end{array}$ & $\begin{array}{l}\text { onsite campaign like } \\
\text { visual inspection, } \\
\text { geometric survey, } \\
\text { damage diagnosis, } \\
\text { control and monitoring }\end{array}$ \\
\hline 59 & Karapetrou et al. [100] & AHEPA hospital & 8 & sensor & $\begin{array}{l}\text { Predict seismic } \\
\text { vulnerability }\end{array}$ \\
\hline 60 & Lorenzoni et al. [101] & $\begin{array}{l}\text { Two heritage building } \\
\text { (Conegliano cathedral } \\
\text { and roman } \\
\text { Amphitheatre (arena)) }\end{array}$ & - & $\begin{array}{c}\text { Single-axis } \\
\text { piezoelectric } \\
\text { accelerometer and } \\
\text { displacement } \\
\text { transducers } \\
\text { integrated with } \\
\text { humid- } \\
\text { ity/temperature } \\
\text { sensors }\end{array}$ & $\begin{array}{l}\text { For damage } \\
\text { identifications }\end{array}$ \\
\hline 61 & Fan et al. [102] & $\begin{array}{c}\text { Guangzhou new TV } \\
\text { tower }\end{array}$ & 32 & $\begin{array}{l}\text { accelerometer, } \\
\text { strain gauge }\end{array}$ & $\begin{array}{l}\text { (ResNet) approach } \\
\text { based on vibration } \\
\text { signal denoising }\end{array}$ \\
\hline 62 & Trifunac et al. [109] & RC building & 7 & - & $\begin{array}{l}\text { Monitoring for damage } \\
\text { prediction }\end{array}$ \\
\hline 63 & Cabboi et al. [111] & $\begin{array}{l}\text { Heritage building (san } \\
\text { Vittore bell tower) }\end{array}$ & - & $\begin{array}{l}\text { piezoelectric } \\
\text { accelerometer }\end{array}$ & $\begin{array}{l}\text { carried out real-time } \\
\text { monitoring and FEM }\end{array}$ \\
\hline 64 & Isidori et al. [113] & 3-story building & 3 & $\begin{array}{c}\text { MEMS sensors and } \\
\text { linear } \\
\text { accelerometer }\end{array}$ & $\begin{array}{l}\text { To spot the distribution, } \\
\text { occurring and rise of } \\
\text { local damage and } \\
\text { estimate the global } \\
\text { damage }\end{array}$ \\
\hline 65 & Kaneko et al. [114] & 6-story building & 6 & - & $\begin{array}{c}\text { To identify the severity } \\
\text { of damage adopting } \\
\text { damage detection } \\
\text { technique }\end{array}$ \\
\hline 66 & $\begin{array}{c}\text { Rahmani and } \\
\text { Todorovska [117] }\end{array}$ & Millikan library & 9 & - & $\begin{array}{c}\text { Suggested two } \\
\text { algorithms TSM and } \\
\text { LSQ }\end{array}$ \\
\hline 67 & Yuen and Kuok [118] & 22-story building & 22 & accelerometer & $\begin{array}{l}\text { To predict modal } \\
\text { frequency }\end{array}$ \\
\hline 68 & Unzu et al. [127] & $\begin{array}{c}\text { Telecommunication } \\
\text { tower }\end{array}$ & - & $\begin{array}{l}\text { fibre optic sensors } \\
\text { with fibre optic } \\
\text { accelerometer and } \\
\text { KNX sensors }\end{array}$ & $\begin{array}{l}\text { Predict reliability, } \\
\text { mechanical properties, } \\
\text { and thermal properties }\end{array}$ \\
\hline 69 & Xu et al. [128] & $\begin{array}{l}1 \text { Main Building and } \\
\text { podium structure }\end{array}$ & 12 and 3 & $\begin{array}{l}\text { charge amplifier, } \\
\text { accelerometers, } \\
\text { and current eddy } \\
\text { sensors }\end{array}$ & $\begin{array}{l}\text { Anticipate damage of } \\
\text { the building by FRF }\end{array}$ \\
\hline
\end{tabular}


Table A1. Cont.

\begin{tabular}{|c|c|c|c|c|c|}
\hline No. & Source by Author & $\begin{array}{l}\text { Subject of Study } \\
\text { (Type of Building) }\end{array}$ & $\begin{array}{l}\text { Number of } \\
\text { Stories }\end{array}$ & $\begin{array}{c}\text { Types of Sensors } \\
\text { Used }\end{array}$ & Measured Parameters \\
\hline 70 & Su et al. [132] & $\begin{array}{c}\text { Shear building model } \\
\text { and non shear } \\
\text { building model }\end{array}$ & 6 and 5 & Accelerometer & $\begin{array}{l}\text { To measure damage in } \\
\text { each storey using } \\
\text { substructural } \\
\text { frequencies }\end{array}$ \\
\hline 71 & Grinzato et al. [134] & $\begin{array}{l}\text { Historic building } \\
\text { (Venice's arsenal) }\end{array}$ & - & IR thermography & $\begin{array}{c}\text { To monitor moisture } \\
\text { content, finishing status, } \\
\text { and walls hidden } \\
\text { structure }\end{array}$ \\
\hline 72 & Madan [137] & 8-story building & 8 & - & $\begin{array}{c}\text { Anticipate } \\
\text { earthquake-induced } \\
\text { vibration in building }\end{array}$ \\
\hline 73 & Boutet et al. [138] & School building & - & HOBO sensors, & $\begin{array}{l}\text { To predict lighting } \\
\text { thermal and } \\
\text { hygrothermal behavior } \\
\text { during the autumn } \\
\text { season }\end{array}$ \\
\hline 74 & Jiang et al. [140] & Shear beam model & 7 & - & Damage identification \\
\hline 75 & Kim et al. [141] & Kart Hall & - & $\begin{array}{l}\text { Vibrating wire } \\
\text { strain gauges }\end{array}$ & $\begin{array}{c}\text { Monitoring of } \\
\text { under-construction } \\
\text { building for detection of } \\
\text { damage }\end{array}$ \\
\hline 76 & Hajdukiewicz et al. [142] & $\begin{array}{c}2 \text { educational } \\
\text { buildings (ICLS and } \\
\text { EB) }\end{array}$ & - & $\begin{array}{l}\text { Various gauges } \\
\text { and sensors }\end{array}$ & $\begin{array}{l}\text { Indoor environment and } \\
\text { energy consumption in } \\
\text { the building }\end{array}$ \\
\hline 77 & Hagiwara et al. [145] & 5-story building & 5 & Vibration sensors & $\begin{array}{l}\text { Suggested SVM for } \\
\text { damage prediction }\end{array}$ \\
\hline 78 & Na et al. [146] & shear beam model & 20 & - & $\begin{array}{c}\text { Implementing genetic } \\
\text { algorithms using a } \\
\text { flexibility matrix based } \\
\text { on a damage evaluation } \\
\text { method }\end{array}$ \\
\hline 79 & $\begin{array}{c}\text { Kopsaftopoulos et al. } \\
{[151]}\end{array}$ & Truss building & - & Strain gauges & $\begin{array}{l}\text { To diagnose the } \\
\text { building's damage }\end{array}$ \\
\hline
\end{tabular}

\section{References}

1. Zonno, G.; Aguilar, R.; Boroschek, R.; Lourenço, P.B. Analysis of the long and short-term effects of temperature and humidity on the structural properties of adobe buildings using continuous monitoring. Eng. Struct. 2019, 196, 109299. [CrossRef]

2. Kilic, G. Using advanced NDT for historic buildings: Towards an integrated multidisciplinary health assessment strategy. J. Cult. Herit. 2015, 16, 526-535. [CrossRef]

3. Gopinath, V.K.; Ramadoss, R. Review on structural health monitoring for restoration of heritage buildings. Mater. Today Proc. 2021, 43. [CrossRef]

4. Ma, J.; Pines, D.J. Damage detection in a building structure model under seismic excitation using dereverberated wave mechanics. Eng. Struct. 2003, 25, 385-396. [CrossRef]

5. Kao, C.Z.; Hung, S.-L. Detection of structural damage via free vibration responses generated by approximating artificial neural networks. Comput. Struct. 2003, 81, 2631-2644. [CrossRef]

6. Xia, Y.; Zhang, P.; Ni, Y.-Q.; Zhu, H.-P. Deformation monitoring of a super-tall structure using real-time strain data. Eng. Struct. 2014, 67, 29-38. [CrossRef]

7. Park, S.W.; Park, H.S.; Kim, J.H.; Adeli, H. 3D displacement measurement model for health monitoring of structures using a motion capture system. Measurement 2015, 59, 352-362. [CrossRef]

8. Hattab, O.; Chaari, M.; Franchek, M.A.; Wassar, T. An adaptive modeling approach to structural health monitoring of multistory buildings. J. Sound Vib. 2019, 440, 239-255. [CrossRef] 
9. $\mathrm{Wu}$, J.R.; Li, Q.S. Structural parameter identification and damage detection for a steel structure using a two-stage finite element model updating method. J. Constr. Steel Res. 2006, 62, 231-239. [CrossRef]

10. Ye, X.W.; Xi, P.S.; Su, Y.H.; Chen, B.; Han, J.P. Stochastic charakterization of wind field characteristics of an arch bridge instrumented with structural health monitoring system. Struct. Saf. 2018, 71, 47-56. [CrossRef]

11. Adamcová, D.; Barton, S.; Osinski, P.; Pasternak, G.; Podlasek, A.; Vaverková, M.D.; Koda, E. Analytical modelling of MSW landfill surface displacement based on GNSS monitoring. Sensors 2020, 20, 5998. [CrossRef] [PubMed]

12. Olivera López, J.J.; Vergara Reyes, L.; Oyarzo Vera, C. Structural health assessment of a R/C building in the coastal area of Concepcion, Chile. Procedia Eng. 2017, 199, 2214-2219. [CrossRef]

13. Yan, K.; Zhang, Y.; Yan, C.; Xu, S.; Zhang, S. Fault diagnosis method of sensors in building structural health monitoring system based on communication load optimization. Comput. Commun. 2020, 159, 310-316. [CrossRef]

14. Roghaei, M.; Zabihollah, A. An Efficient and Reliable Structural Health Monitoring System for Buildings after Earthquake. APCBEE Procedia 2014, 9, 309-316. [CrossRef]

15. Zhou, C.; Chase, J.G.; Rodgers, G.W.; Huang, B.; Xu, C. Effective Stiffness Identification for Structural Health Monitoring of Reinforced Concrete Building using Hysteresis Loop Analysis. Procedia Eng. 2017, 199, 1074-1079. [CrossRef]

16. Pierdicca, A.; Clementi, F.; Mezzapelle, P.; Fortunati, A.; Lenci, S. One-year monitoring of a reinforced concrete school building: Evolution of dynamic behavior during retrofitting works. Procedia Eng. 2017, 199, 2238-2243. [CrossRef]

17. Demetriou, M.A. On-Line Damage Detection, Assessment and Accommodation in Civil Infrastructure Systems. IFAC Process. 2000, 33, 759-764. [CrossRef]

18. Dong, Y.; Li, M.; Lai, M. Structural damage detection using empirical-mode decomposition and vector autoregressive moving average model. Soil Dyn. Earthq. Eng. 2010, 30, 133-145. [CrossRef]

19. Yang, Z.; Dutta, U.; Xiong, F.; Biswas, N.; Benz, H. Seasonal frost effects on the dynamic behavior of a twenty-story office building. Cold Reg. Sci. Technol. 2008, 51, 76-84. [CrossRef]

20. Antunes, P.; Lima, H.; Varum, P.; André, P. Optical fiber sensors for static and dynamic health monitoring of civil engineering infrastructures: Abode wall case study. Measurement 2021, 45, 1695-1705. [CrossRef]

21. Zhao, X.; Yuan, S.; Zhou, H.; Sun, H.; Qiu, L. An evaluation on the multi-agent system based structural health monitoring for large scale structures. Expert Syst. Appl. 2009, 36, 4900-4914. [CrossRef]

22. Hison, C.; Ausanio, G.; Barone, A.C.; Iannotti, V.; Pepe, E.; Lanotte, L. Magnetoelastic sensor for real-time monitoring of elastic deformation and fracture alarm. Sens. Actuators A Phys. 2005, 125, 10-14. [CrossRef]

23. Mahjoubi, S.; Barhemat, R.; Bao, Y. Optimal placement of triaxial accelerometers using hypotrochoid spiral optimization algorithm for automated monitoring of high-rise buildings. Autom. Constr. 2019, 118, 103273. [CrossRef]

24. Sajedi, S.O.; Liang, X. A data-driven framework for near real-time and robust damage diagnosis of building structures. Struct. Control Health Monit. 2020, 27, e2488. [CrossRef]

25. Gao, W.; Li, H.; Ho, S.C.M. A novel embeddable tubular piezoceramics-based smart aggregate for damage detection in twodimensional concrete structures. Sensors 2019, 19, 1501. [CrossRef]

26. Chatzis, M.N.; Chatzi, E.N.; Smyth, A.W. An experimental validation of time domain system identification methods with fusion of heterogeneous data. Earthq. Eng. Struct Dyn. 2015, 44, 523-547. [CrossRef]

27. Soltaninejad, M.; Soroushian, S.; Livani, H. Application of short-time matrix pencil method for high-frequency damage detection in structural system. Struct. Control Health Monit. 2020, 27, e2589. [CrossRef]

28. García-Macías, E.; Ubertini, F. Automated operational modal analysis and ambient noise deconvolution interferometry for the full structural identification of historic towers: A case study of the Sciri Tower in Perugia, Italy. Eng. Struct. 2020, $215,110615$. [CrossRef]

29. Sun, H.; Al-Qazweeni, J.; Parol, J.; Kamal, H.; Chen, Y.; Büyüköztürk, O. Computational modeling of a unique tower in Kuwait for structural health monitoring: Numerical investigations. Struct. Control Health Monit. 2019, 26, e2317. [CrossRef]

30. Chellini, G.; De Roeck, L.; Nardini, W. Salvatore, Damage detection of a steel-concrete composite frame by a multilevel approach: Experimental measurements and modal identification. Earthq. Eng. Struct. Dyn. 2008, 37, 1763-1783. [CrossRef]

31. Morales-Valdez, J.; Alvarez-Icaza, L.; Escobar, J.A. Damage Localization in a Building Structure during Seismic Excitation. Shock Vib. 2020, 2020, 8859527. [CrossRef]

32. Valinejadshoubi, M.; Bagchi, A.; Moselhi, O. Development of a BIM-Based Data Management System for Structural Health Monitoring with Application to Modular Buildings: Case Study. J. Comput. Civ. Eng. 2019, 33, 1-16. [CrossRef]

33. Pachón, P.; Infantes, M.; Camara, M.; Compan, V.; Garcia-Macias, E.; Friswell, M.I.; Castro-Triguero, R. Evaluation of optimal sensor placement algorithms for the Structural Health Monitoring of architectural heritage. Application to the Monastery of San Jerónimo de Buenavista (Seville, Spain). Eng. Struct. 2019, 202, 109843. [CrossRef]

34. Frigui, F.; Faye, J.P.; Martin, C.; Dalverny, O.; Peres, F.; Judenherc, S. Global methodology for damage detection and localization in civil engineering structures. Eng. Struct. 2018, 171, 686-695. [CrossRef]

35. Suhaimi, S.A.; Azemi, S.N.; Soh, P.J.; Rashidi Bin, C.B.M.; Al-Hadi, A.A. Highly sensitive frequency selective surface for structural health monitoring system. Indones. J. Electr. Eng. Comput. Sci. 2019, 14, 523-528. [CrossRef]

36. García-Macías, E.; Ubertini, F. MOVA/MOSS: Two integrated software solutions for comprehensive Structural Health Monitoring of structures. Mech. Syst. Signal Process. 2020, 143, 106830. [CrossRef] 
37. Li, Q.; He, Y.; Zhou, K.; Han, X.; He, Y.; Shu, Z. Structural health monitoring for a $600 \mathrm{~m}$ high skyscraper. Struct. Des. Tall Spec. Build. 2018, 27, e1490. [CrossRef]

38. Zhang, F.-L.; Yang, Y.P.; Xiong, H.B.; Yang, J.-H.; Yu, Z. Structural health monitoring of a 250-m super-tall building and operational modal analysis using the fast Bayesian FFT method. Struct. Control Health Monit. 2019, 26, e2383. [CrossRef]

39. Modena, C.; Lorenzoni, F.; Caldon, M.; da Porto, F. Structural health monitoring: A tool for managing risks in sub-standard conditions. J. Civ. Struct. Health Monit. 2016, 6, 365-375. [CrossRef]

40. Mustafa, F.H.W.; Azemi, S.N.; Jamlos, M.F.; Al-Hadi, A.A.; Soh, P.J. Passive sensor frequency selective surface for structural health monitoring. Indones. J. Electr. Eng. Comput. Sci. 2019, 14, 744-750. [CrossRef]

41. Aguilar, R.; Zonno, G.; Lozano, G.; Boroschek, R.; Lourenço, P.B. Vibration-Based Damage Detection in Historical Adobe Structures: Laboratory and Field Applications. Int. J. Archit. Herit. 2019, 13, 1005-1028. [CrossRef]

42. Brownjohn, J.M.V.; de Stefano, A.; Xu, Y.L.; Wenzel, H.; Aktan, A.E. Vibration-based monitoring of civil infrastructure: Challenges and successes. J. Civ. Struct. Health Monit. 2011, 1, 79-95. [CrossRef]

43. Coletta, G.; Miraglia, G.; Pecorelli, M.; Ceravolo, R.; Cross, E.; Surace, C.; Worden, K. Use of the cointegration strategies to remove environmental effects from data acquired on historical buildings. Eng. Struct. 2019, 183, 1014-1026. [CrossRef]

44. García-Macías, E.; Venanzi, I.; Ubertini, F. Metamodel-based pattern recognition approach for real-time identification of earthquake-induced damage in historic masonry structures. Autom. Constr. 2020, 120, 103389. [CrossRef]

45. Lam, H.F.; Zhang, F.L.; Ni, Y.C.; Hu, J. Operational modal identification of a boat-shaped building by a Bayesian approach. Eng. Struct. 2017, 138, 381-393. [CrossRef]

46. Lorenzoni, F.; Caldon, M.; da Porto, F.; Modena, C.; Aoki, T. Post-earthquake controls and damage detection through structural health monitoring: Applications in l'Aquila. J. Civ. Struct. Health Monit. 2018, 8, 217-236. [CrossRef]

47. Bhalla, S.; Kaur, N. Prognosis of low-strain fatigue induced damage in reinforced concrete structures using embedded piezotransducers. Int. J. Fatigue 2018, 113, 98-112. [CrossRef]

48. Kaya, Y.; Safak, E. Real-time analysis and interpretation of continuous data from structural health monitoring (SHM) systems. Bull. Earthq. Eng. 2015, 13, 917-934. [CrossRef]

49. Cheng, J.J.; Guo, H.Y.; Wang, Y.S. Structural Nonlinear Damage Detection Method Using AR/ARCH Model. Int. J. Struct. Stab. Dyn. 2017, 17, 1750083. [CrossRef]

50. Rahmani, M.; Ebrahimian, M.; Todorovska, M.I. Time-wave velocity analysis for early earthquake damage detection in buildings: Application to a damaged full-scale RC building. Earthq. Eng. Struct. Dyn. 2014, 44, e.2539. [CrossRef]

51. Musafere, F.; Sadhu, A.; Liu, K. Towards damage detection using blind source separation integrated with time-varying autoregressive modeling. Smart Mater. Struct. 2015, 25, 15013. [CrossRef]

52. Yan, W.J.; Zhao, M.Y.; Sun, Q.; Ren, W.X. Transmissibility-based system identification for structural health Monitoring: Fundamentals, approaches, and applications. Mech. Syst. Signal Process. 2019, 117, 453-482. [CrossRef]

53. Behnia, A.; Chai, H.K.; Shiotani, T. Advanced structural health monitoring of concrete structures with the aid of acoustic emission. Constr. Build. Mater. 2014, 65, 282-302. [CrossRef]

54. Fortino, G.; Guerrieri, A.; Ohare, G.M.P.; Ruzzelli, A. A flexible building management framework based on wireless sensor and actuator networks. J. Netw. Comput. Appl. 2012, 35, 934-1952. [CrossRef]

55. Hackmann, G.; Sun, F.; Castaneda, N.; Lu, C.; Dyke, S. A holistic approach to decentralized structural damage localization using wireless sensor networks. Comput. Commun. 2012, 36, 29-41. [CrossRef]

56. Ierimonti, L.; Venanzi, I.; Cavalagli, N.; Comodini, F.; Ubertini, F. An innovative continuous Bayesian model updating method for base-isolated RC buildings using vibration monitoring data. Mech. Syst. Signal Process. 2020, 139, 106600. [CrossRef]

57. Carden, E.P.; Brownjohn, J.M.W. ARMA modelled time-series classification for structural health monitoring of civil infrastructure. Mech. Syst. Signal Process. 2008, 22, 295-314. [CrossRef]

58. Wang, J.F.; Lin, C.C.; Yen, S.M. A story damage index of seismically-excited buildings based on modal frequency and mode shape. Eng. Struct. 2007, 29, 2143-2157. [CrossRef]

59. Ramos, L.F.; Aguilar, R.; Lourenço, P.B.; Moreira, S. Dynamic structural health monitoring of Saint Torcato church. Mech. Syst. Signal Process. 2013, 35, 1-15. [CrossRef]

60. Mejri, O.; Palomo Del Barrio, E.; Ghrab-Morcos, N. Energy performance assessment of occupied buildings using model identification techniques. Energy Build. 2011, 43, 285-299. [CrossRef]

61. Bhalla, S.; Soh, C.K. High frequency piezoelectric signatures for diagnosis of seismic/blast induced structural damages. NDT E Int. 2004, 37, 23-33. [CrossRef]

62. Pesci, A.; Casula, G.; Boschi, E. Laser scanning the Garisenda and Asinelli towers in Bologna (Italy): Detailed deformation patterns of two ancient leaning buildings. J. Cult. Herit. 2011, 12, 117-127. [CrossRef]

63. Xu, C.; Chase, J.G.; Rodgers, G.W. Physical parameter identification of nonlinear base-isolated buildings using seismic response data. Comput. Struct. 2014, 145, 47-57. [CrossRef]

64. Saisi, A.; Gentile, C.; Ruccolo, A. Pre-diagnostic prompt investigation and static monitoring of a historic bell-tower. Constr. Build. Mater. 2016, 122, 833-844. [CrossRef]

65. Butt, F.; Omenzetter, P. Seismic response trends evaluation and finite element model calibration of an instrumented RC building considering soil-structure interaction and non-structural components. Eng. Struct. 2014, 65, 111-123. [CrossRef] 
66. Zhang, Q.; Jankowski, Ł.; Duan, Z. Simultaneous identification of excitation time histories and parametrized structural damages. Mech. Syst. Signal Process. 2012, 33, 56-68. [CrossRef]

67. Kane, M.B.; Peckens, C.; Lynch, J.P. 16-Design and selection of wireless structural monitoring systems for civil infrastructures. In Sensor Technologies for Civil Infrastructures; Woodhead Publishing: Cambridge, UK, 2014; Volume 1, pp. 446-479.

68. Hill-King, M. Smart structures through embedding optical strain sensing. Smart Mater. Bull. 2010, 5, 7-10. [CrossRef]

69. Habel, W.R. 4-Structural health monitoring systems for reinforced concrete structures. In Non-Destructive Evaluation of Reinforced Concrete Structures; Non-Destructive Testing Methods; Woodhead Publishing: Cambridge, UK, 2010; pp. 63-94.

70. Wang, C.; Xiao, J.; Zhang, C.; Xiao, X. Structural health monitoring and performance analysis of a 12-story recycled aggregate concrete structure. Eng. Struct. 2019, 205, 110102. [CrossRef]

71. Bulajić, B.; Todorovska, M.I.; Manić, M.D. Trifunac, Structural health monitoring study of the ZOIL building using earthquake records. Soil Dyn. Earthq. Eng. 2020, 133, 106105. [CrossRef]

72. Ayyildiz, C.; Erdem, H.E.; Dirikgil, T.; Dugenci, O.; Kocak, T.; Altun, F.; Gungor, V.C. Structure health monitoring using wireless sensor networks on structural elements. Ad Hoc Netw. 2019, 82, 68-76. [CrossRef]

73. Jang, W.S.; Healy, W.M.; Skibniewski, M.J. Wireless sensor networks as part of a web-based building environmental monitoring system. Autom. Constr. 2008, 17, 729-736. [CrossRef]

74. Yang, N.J.; Huang, H. Sequential non-linear least-square estimation for damage identification of structures with unknown inputs and unknown outputs. Int. J. Non Linear Mech. 2007, 42, 789-801. [CrossRef]

75. Ivanović, S.S.; Trifunac, M.D.; Novikova, E.I.; Gladkov, A.A.; Todorovska, M.I. Ambient vibration tests of a seven-story reinforced concrete building in Van Nuys, California, damaged by the 1994 north ridge earthquake. Soil Dyn. Earthq. Eng. 2000, 19, 391-411. [CrossRef]

76. Jin, S.S.; Cho, S.; Jung, H.J. Adaptive reference updating for vibration-based structural health monitoring under varying environmental conditions. Comput. Struct. 2015, 158, 211-224. [CrossRef]

77. Chang, C.M.; Lin, T.K.; Chang, C.W. Applications of neural network models for structural health monitoring based on derived modal properties. Measurement 2018, 129, 457-470. [CrossRef]

78. Pham, H.A. Solving inverse problem in Structural Health Monitoring by differential evolution algorithm. In Proceedings of the 14th East Asia-Pacific Conference on Structural Engineering and Construction (EASEC-14), Ho Chi Minh City, Vietnam, 6-8 January 2016; pp. 2042-2049.

79. Yuan, F.-G.; Zargar, S.A.; Chen, Q.; Wang, S. Machine learning for structural health monitoring: Challenges and opportunities. In Proceedings of the SPIE 11379, Sensors and Smart Structures Technologies for Civil, Mechanical, and Aerospace Systems. SPIE 2020, 1137903. [CrossRef]

80. Kyriacou, A.; Michaelides, M.P.; Eliades, D.G.; Panayiotou, C.G.; Polycarpou, M.M. COMOB: A MATLAB toolbox for sensor placement and contaminant event monitoring in multi-zone buildings. Build. Environ. 2018, 154, 348-361. [CrossRef]

81. Nguyen, T.; Chan, T.H.T.; Thambiratnam, D.P.; King, L. Development of a cost-effective and flexible vibration DAQ system for long-term continuous structural health monitoring. Mech. Syst. Signal Process. 2015, 64-65, 313-324. [CrossRef]

82. Yi, T.H.; Bin Huang, H.; Li, H.N. Development of sensor validation methodologies for structural health monitoring: A comprehensive review. MEASUREMENT 2017, 109, 200-214. [CrossRef]

83. Todorovska, M.I.; Trifunac, M.D. Earthquake damage detection in the Imperial County Services Building I: The data and time-frequency analysis. Soil Dyn. Earthq. Eng. 2007, 27, 564-576. [CrossRef]

84. Oh, B.K.; Kim, K.J.; Kim, Y.; Park, H.S.; Adeli, H. Evolutionary learning based sustainable strain sensing model for structural health monitoring of high-rise buildings. Appl. Soft. Comput. 2017, 58, 576-585. [CrossRef]

85. Çelebi, M. GPS in dynamic monitoring of long-period structures. Soil Dyn. Earthq. Eng. 2000, 20, 477-483. [CrossRef]

86. Pisello, A.L.; Castaldo, V.L.; Piselli, C.; Fabiani, C.; Cotana, F. How peers' personal attitudes affect indoor microclimate and energy need in an institutional building: Results from a continuous monitoring campaign in summer and winter conditions. Energy Build. 2016, 126, 485-497. [CrossRef]

87. Theiler, M.; Smarsly, K. IFC Monitor-An IFC schema extension for modeling structural health monitoring systems. Adv. Eng. Inform. 2018, 37, 54-65. [CrossRef]

88. Chen, B.; Xu, Y.L. Integrated vibration control and health monitoring of building structures using semi-active friction dampers: Part II-Numerical investigation. Eng. Struct. 2008, 30, 573-587. [CrossRef]

89. Haque, M.E.; Hannan, M.A.; Islam, M.R.; Rahman, M.H.H. Investigations optimum scheduling and TCP mechanism of hybrid topology sensor network in building SHM. Optik 2016, 127, 3218-3224. [CrossRef]

90. Alonso, L.; Barbarán, J.; Chen, J.; Díaz, M.; Llopis, L.; Rubio, B. Middleware and communication technologies for structural health monitoring of critical infrastructures: A survey. Comput. Stand. Interfaces 2017, 56, 83-100. [CrossRef]

91. Pingue, F.; Petrazzuoli, S.M.; Obrizzo, F.; Tammaro, U.; De Martino, P.; Zuccaro, G. Monitoring system of buildings with high vulnerability in presence of slow ground deformations (The Campi Flegrei, Italy, case). Measurement 2011, 44, 1628-1644. [CrossRef]

92. Ma, P.; Lin, H.; Lan, H.; Chen, F. Multi-dimensional SAR tomography for monitoring the deformation of newly built concrete buildings. ISPRS J. Photogramm. Remote Sens. 2015, 106, 118-128. [CrossRef]

93. Zapico, J.L.; González, M.P. Numerical simulation of a method for seismic damage identification in buildings. Eng. Struct. 2006, 28, 255-263. [CrossRef] 
94. Park, H.S.; Oh, B.K. Real-time structural health monitoring of a supertall building under construction based on visual modal identification strategy. Autom. Constr. 2017, 85, 273-289. [CrossRef]

95. Fujino, Y.; Siringoringo, D.M.; Ikeda, Y.; Nagayama, T.; Mizutani, T. Research and Implementations of Structural Monitoring for Bridges and Buildings in Japan. Engineering 2019, 5, 1093-1119. [CrossRef]

96. He, J.; Xu, Y.L.; Zhan, S.; Huang, Q. Structural control and health monitoring of building structures with unknown ground excitations: Experimental investigation. J. Sound Vib. 2017, 390, 23-38. [CrossRef]

97. Gao, F.; Zhou, H.; Liang, H.; Weng, S.; Zhu, H. Structural deformation monitoring and numerical simulation of a supertall building during construction stage. Eng. Struct. 2020, 209, 110033. [CrossRef]

98. Saadat, S.; Noori, M.N.; Buckner, G.D.; Furukawa, T.; Suzuki, Y. Structural health monitoring and damage detection using an intelligent parameter varying (IPV) technique. Int. J. Non Linear Mech. 2004, 39, 1687-1697. [CrossRef]

99. Masciotta, M.G.; Ramos, L.F.; Lourenço, P.B. The importance of structural monitoring as a diagnosis and control tool in the restoration process of heritage structures: A case study in Portugal. J. Cult. Herit. 2017, 27, 36-47. [CrossRef]

100. Karapetrou, S.; Manakou, M.; Bindi, D.; Petrovic, B.; Pitilakis, K. Time-building specific' seismic vulnerability assessment of a hospital RC building using field monitoring data. Eng. Struct. 2016, 112, 114-132. [CrossRef]

101. Lorenzoni, F.; Casarin, F.; Caldon, M.; Islami, K.; Modena, C. Uncertainty quantification in structural health monitoring: Applications on cultural heritage buildings. Mech. Syst. Signal Process. 2016, 66-67, 268-281. [CrossRef]

102. Fan, G.; Li, J.; Hao, H. Vibration signal denoising for structural health monitoring by residual convolutional neural networks. Measurement 2020, 157, 107651. [CrossRef]

103. Lofrano, E.; Paolone, A.; Vasta, M. A perturbation approach for the identification of uncertain structures. Int. J. Dyn. Control 2016, 4, 204-212. [CrossRef]

104. Lofrano, E.; Paolone, A.; Vasta, M. Identification of Uncertain Vibrating Beams through a Perturbation Approach. ASCE ASME J. Risk Uncertain. Eng. Syst. Part A Civ. Eng. 2016, 2, 1-12. [CrossRef]

105. Kato, T. Perturbation Theory for Linear Operators; Springer: Amsterdam, The Netherlands, 1995; Volume 132, p. 623. [CrossRef]

106. Adhikari, S. Rates of Change of Eigenvalues and Eigenvectors in Damped Dynamic System. AIAA J. 1999, 37, 1452-1458. [CrossRef]

107. Fox, R.L.; Kapoor, M.P. Rates of change of eigenvalues and eigenvectors. AIAA J. 1968, 6, 2426-2429. [CrossRef]

108. Park, J.W.; Lee, J.J.; Jung, H.J.; Myung, H. Vision-based displacement measurement method for high-rise building structures using partitioning approach. NDT E Int. 2010, 43, 642-647. [CrossRef]

109. Trifunac, M.D.; Ivanović, S.S.; Todorovska, M.I. Wave propagation in a seven-story reinforced concrete building. III. Damage detection via changes in wavenumbers. Soil Dyn. Earthq. Eng. 2003, 23, 65-75. [CrossRef]

110. Shih, H.W.; Thambiratnam, D.P.; Chan, T.H.T. Vibration based structural damage detection in flexural members using multicriteria approach. J. Sound Vib. 2009, 323, 645-661. [CrossRef]

111. Cabboi, A.; Gentile, C.; Saisi, A. From continuous vibration monitoring to FEM-based damage assessment: Application on a stone-masonry tower. Constr. Build. Mater. 2017, 156, 252-265. [CrossRef]

112. De Lautour, O.R.; Omenzetter, P. Prediction of seismic-induced structural damage using artificial neural networks. Eng. Struct. 2009, 31, 600-606. [CrossRef]

113. Isidori, E.D.C.; Cristalli, C.; Soria, L.; Lenci, S. Proof of concept of the structural health monitoring of framed structures by a novel combined experimental and theoretical approach. Struct. Control Health Monit. 2016, 23, 802-824. [CrossRef]

114. Kaneko, Y.; Mita, A.; Mihashi, H. Quantitative approach for damage detection of reinforced concrete frames. Earthq. Eng. Eng. Vib. 2003, 2, 147-158. [CrossRef]

115. Monavari, B.; Chan, T.H.T.; Nguyen, A.; Thambiratnam, D.P. Structural Deterioration Detection Using Enhanced Autoregressive Residuals. Int. J. Struct. Stab. Dyn. 2018, 18, 1850160. [CrossRef]

116. Leng, J.S.; Barnes, R.A.; Hameed, A.; Winter, D.; Teltow, J.; Mays, G.C.; Fernando, G.F. Structural NDE of concrete structures using protected EFPI and FBG sensors. Sens. Actuators A Phys. 2006, 126, 340-347. [CrossRef]

117. Rahmani, M.; Todorovska, M.I. 1D system identification of buildings during earthquakes by seismic interferometry with waveform inversion of impulse responses-method and application to Millikan library. Soil Dyn. Earthq. Eng. 2013, 47, 157-174. [CrossRef]

118. Yuen, K.V.; Kuok, S.C. Ambient interference in long-term monitoring of buildings. Eng. Struct. 2013, 32, 2379-2386. [CrossRef]

119. Smarsly, K.; Law, K.H. A migration-based approach towards resource-efficient wireless structural health monitoring. Adv. Eng. Inform. 2013, 27, 625-635. [CrossRef]

120. Picozzi, M. An attempt of real-time structural response assessment by an interferometric approach: A tailor-made earthquake early warning for buildings. Soil Dyn. Earthq. Eng. 2012, 38, 109-118. [CrossRef]

121. Villalba, S.; Casas, J.R. Application of optical fiber distributed sensing to health monitoring of concrete structures. Mech. Syst. Signal Process. 2013, 39, 441-451. [CrossRef]

122. White, L. A reduced three-dimensional dynamic structural model for structural health assessment. Appl. Math. Comput. 2006, 182, 572-588. [CrossRef]

123. Severino, R.; Gomes, R.; Alves, M.; Sousa, P.; Ramos, L.F.; Aguilar, L.; Tovar, E.; Lourenco, P.B. A Wireless Sensor Network platform for structural health monitoring: Enabling accurate and synchronized measurements through COTS+custom-based design. IFAC Proceedings Volumes. 2010, 43, 375-382. [CrossRef] 
124. Yang, J.N.; Lin, S.; Pan, S. Damage Detection of a Health Monitoring Benchmark Building Using Hilbert-Huang Spectral Analysis. Adv. Build. Technol. 2002, 2, 1017-1024.

125. Lee, W.; Cheon, M.; Hyun, C.H.; Park, M. Development of building fire safety system with automatic security firm monitoring capability. Fire Saf. J. 2013, 58, 65-73. [CrossRef]

126. Chase, J.G.; Begoc, V.; Barroso, L.R. Efficient structural health monitoring for a benchmark structure using adaptive RLS filters. Comput. Struct. 2005, 83, 639-647. [CrossRef]

127. Unzu, R.; Nazabal, J.A.; Vargas, G.; Hernandez, R.J.; Fernandez-Valdivielso, C.; Urriza, N.; Galarza, M.; Lopez-Amo, M. Fiber optic and KNX sensors network for remote monitoring a new building cladding system. Autom. Constr. 2013, 30, 9-14. [CrossRef]

128. Xu, Y.L.; Huang, Q.; Zhan, S.; Su, Z.Q.; Liu, H.J. FRF-based structural damage detection of controlled buildings with podium structures: Experimental investigation. J. Sound Vib. 2014, 333, 2762-2775. [CrossRef]

129. Täljsten, B.; Carolin, A. FRP Strengthening of Building and Civil Structures in Sweden-A Review and Future Aims. In Advanced Polymer Composites for Structural Applications in Construction; 2004; pp. 763-770.

130. Zhang, J.; Xu, Y.L.; Li, J. Integrated system identification and reliability evaluation of stochastic building structures. Probabilistic Eng. Mech. 2011, 26, 528-538. [CrossRef]

131. Yu, L.; Nazir, B.; Wang, Y. Intelligent power monitoring of building equipment based on Internet of Things technology. Comput. Commun. 2020, 157, 76-84. [CrossRef]

132. Su, W.C.; Huang, C.S.; Hung, S.L.; Chen, L.J.; Lin, W.J. Locating damaged storeys in a shear building based on its sub-structural natural frequencies. Eng. Struct. 2012, 39, 126-138. [CrossRef]

133. Burnett, J.; Yaping, P.D. Mitigation of extremely low frequency magnetic fields from electrical installations in high-rise buildings. Build. Environ. 2003, 37, 769-775. [CrossRef]

134. Grinzato, E.; Bison, P.G.; Marinetti, S. Monitoring of ancient buildings by the thermal method. J. Cult. Herit. 2002, 3, 21-29. [CrossRef]

135. Tan, C.H.; Mahamd Adikan, F.R.; Shee, Y.G.; Yap, B.K. Non-destructive fiber Bragg grating based sensing system: Early corrosion detection for structural health monitoring. Sens. Actuators A Phys. 2017, 268, 61-67. [CrossRef]

136. Krüger, M. 6-Wireless monitoring of reinforced concrete structures. In Non-Destructive Evaluation of Reinforced Concrete Structures; Non-Destructive Testing Methods; Woodhead Publishing: Cambridge, UK, 2010; Volume 2, pp. 111-124.

137. Madan, A. Vibration control of building structures using self-organizing and self-learning neural networks. J. Sound Vib. 2005, 287, 759-784. [CrossRef]

138. Boutet, M.L.; Hernández, A.L.; Jacobo, G.J. Thermo-lighting optimization proposal for school buildings in subtropical hotHumid climates: Monitoring and computer simulation on autumn period. Energy Build. 2016, 128, 785-797. [CrossRef]

139. De Wilde, P.; Coley, D. The implications of a changing climate for buildings. Build. Environ. 2012, 55, 1-7. [CrossRef]

140. Jiang, S.F.; Zhang, C.M.; Zhang, S. Two-stage structural damage detection using fuzzy neural networks and data fusion techniques. Expert Syst. Appl. 2011, 38, 511-519. [CrossRef]

141. Kim, Y.; Park, J.S.; Oh, B.K.; Cho, T.; Kim, J.M.; Kim, S.H.; Park, H.S. Practical wireless safety monitoring system of long-span girders subjected to construction loading a building under construction. Measurement 2019, 146, 524-536. [CrossRef]

142. Hajdukiewicz, M.; Byrne, D.; Keane, M.M.; Goggins, J. Real-time monitoring framework to investigate the environmental and structural performance of buildings. Build. Environ. 2015, 86, 1-16. [CrossRef]

143. Li, H.N.; Li, D.S.; Song, G.B. Recent applications of fiber optic sensors to health monitoring in civil engineering. Eng. Struct. 2004, 26, 1647-1657. [CrossRef]

144. Bakis, C.E.; Nanni, A.; Terosky, J.A.; Koehler, S.W. Self-monitoring, pseudo-ductile, hybrid FRP reinforcement rods for concrete applications. Compos. Sci. Technol. 2002, 61, 815-823. [CrossRef]

145. Hagiwara, H.; Mita, A. Structural Health Monitoring System Using Support Vector Machine. Adv. Build. Technol. $2002,1,8$.

146. Na, C.; Kim, S.P.; Kwak, H.G. Structural damage evaluation using genetic algorithm. J. Sound Vib. 2011, 330, 2772-2783. [CrossRef]

147. Zhang, J.; Sato, T.; Iai, S. Support vector regression for on-line health monitoring of large-scale structures. Struct. Saf. 2006, 28, 392-406. [CrossRef]

148. Cataldo, A.; De Benedetto, E.; Cannazza, G.; Monti, G.; Piuzzi, E. TDR-based monitoring of rising damp through the embedding of wire-like sensing elements in building structures. Measurement 2017, 98, 355-360. [CrossRef]

149. Skutnik, Z.; Sobolewski, M.; Koda, E. An Experimental Assessment of the Water Permeability of Concrete with a Superplasticizer and Admixtures. Materials 2020, 13, 5624. [CrossRef] [PubMed]

150. Ni, Y.Q.; Hua, X.G.; Fan, K.Q.; Ko, J.M. Correlating modal properties with temperature using long-term monitoring data and support vector machine technique. Eng. Struct. 2005, 27, 1762-1773. [CrossRef]

151. Kopsaftopoulos, F.P.; Fassois, S.D. Vibration based health monitoring for a lightweight truss structure: Experimental assessment of several statistical time series methods. Mech. Syst. Signal Process. 2010, 24, 1977-1997. [CrossRef]

152. Górski, W.; Szulc, J. Numerical modelling of non-homogeneous concrete connections in large panel system buildings. Acta Sci. Pol. Archit. 2019, 18, 79-92.

153. Huang, M.; Zhao, W.; Gu, J.; Lei, Y. Damage Identification of a Steel Frame Based on Integration of Time Series and Neural Network under Varying Temperatures. Adv. Civ. Eng. 2020. [CrossRef]

154. Huang, M.S.; Gül, M.; Zhu, H.-P. Vibration-Based Structural Damage Identification under Varying Temperature Effects. J. Aerosp. Eng. 2018, 31, 04018014. [CrossRef] 
155. Huang, M.S.; Cheng, S.; Zhang, H.; Gul, M.; Lu, H. Structural Damage Identification under Temperature Variations Based on PSO-CS Hybrid Algorithm. Int. J. Struct. Stab. Dyn. 2019, 19, 1-28. [CrossRef]

156. Szymczak-Graczyk, A. Numerical Analysis of the Impact of Thermal Spray Insulation Solutions on Floor Loading. Appl. Sci. 2020, 10, 1016. [CrossRef]

157. Huang, M.; Li, X.; Lei, Y.; Gu, J. Structural damage identification based on modal frequency strain energy assurance criterion and flexibility using enhanced Moth-Flame optimization. Structures 2020, 28, 1119-1136. [CrossRef] 